NBER WORKING PAPER SERIES

\title{
WHY HAS IDIOSYNCRATIC RISK BEEN HISTORICALLY LOW IN RECENT YEARS?
}

Söhnke M. Bartram

Gregory W. Brown

René M. Stulz

Working Paper 24270

http://www.nber.org/papers/w24270

\author{
NATIONAL BUREAU OF ECONOMIC RESEARCH \\ 1050 Massachusetts Avenue \\ Cambridge, MA 02138 \\ January 2018
}

Respectively, Professor of Finance, University of Warwick, Professor and Sarah Graham Kenan Distinguished Scholar, Kenan-Flagler Business School, The University of North Carolina at Chapel Hill, and Everett D. Reese Chair of Banking and Monetary Economics, Fisher College of Business, The Ohio State University, NBER, and ECGI. We thank Laura Veldkamp for providing uncertainty index data. We are grateful for useful comments from Andrei Gon-çalves. Bartram gratefully acknowledges the warm hospitality of NYU's Stern School of Business. This paper uses some results from Bartram, Brown, and Stulz (2016) and supersedes it. The views expressed herein are those of the authors and do not necessarily reflect the views of the National Bureau of Economic Research.

At least one co-author has disclosed a financial relationship of potential relevance for this research. Further information is available online at http://www.nber.org/papers/w24270.ack

NBER working papers are circulated for discussion and comment purposes. They have not been peerreviewed or been subject to the review by the NBER Board of Directors that accompanies official NBER publications.

(C) 2018 by Söhnke M. Bartram, Gregory W. Brown, and René M. Stulz. All rights reserved. Short sections of text, not to exceed two paragraphs, may be quoted without explicit permission provided that full credit, including $\odot$ notice, is given to the source. 
Why has Idiosyncratic Risk been Historically Low in Recent Years?

Söhnke M. Bartram, Gregory W. Brown, and René M. Stulz

NBER Working Paper No. 24270

January 2018

JEL No. G10,G11,G12

\section{ABSTRACT}

Since 1965, average idiosyncratic risk (IR) has never been lower than in recent years. In contrast to the high IR in the late 1990s that has drawn considerable attention in the literature, average market-model IR is 44\% lower in 2013-2017 than in 1996-2000. Macroeconomic variables help explain why IR is lower, but using only macroeconomic variables leads to large prediction errors compared to using only firm-level variables. As a result of the dramatic change in the number and composition of listed firms since the late 1990s, listed firms are larger and older. Larger and older firms have lower idiosyncratic risk. Models that use firm characteristics to predict firm-level idiosyncratic risk estimated over 1963-2012 can largely or completely explain why IR is low over 2013-2017. The same changes that bring about historically low IR lead to unusually high market-model R-squareds.

Söhnke M. Bartram

Warwick University

Warwick Buisiness School

Department of Finance

Coventry

CV4 7AL

United Kingdom

s.m.bartram@wbs.ac.uk

Gregory W. Brown

University of North Carolina at Chapel Hill

Kenan-Flagler Business School

gregwbrown@unc.edu
René M. Stulz

The Ohio State University

Fisher College of Business

806A Fisher Hall

Columbus, OH 43210-1144

and NBER

stulz@cob.osu.edu 
Idiosyncratic risk (IR) plays a central role in financial markets. There is an extensive literature (reviewed in the next section) trying to understand the determinants of time-series variation in average idiosyncratic risk. This literature is especially focused on understanding the high average IR in the late 1990s and the overall increase in average IR from the 1960s to the early 2000s. To date, there is no consensus in the literature. In this paper, we show that IR is historically low over the recent years and explore this empirical fact to shed light on the determinants of IR variation. ${ }^{1}$ Our key result is that the low IR of the recent years can be explained by variation in the characteristics of listed firms. We argue that such variation is linked to the dramatic changes in the number and composition of public firms that have taken place since the late 1990s.

The literature has provided several explanations for variation in IR, and they can be broadly classified as based on (i) macroeconomic variables (including market risk) and (ii) firm characteristics. We follow this classification and explore both as possible explanations for the low IR of the recent years. In the first part of the paper, we show that macroeconomic models of IR predict a lower than historical average IR for 2013-2017, but they cannot explain why IR is so low. While there is a strong relation between market risk and IR, market risk in recent years is not significantly lower than most years in our sample period. Using the historical relation between IR and macroeconomic variables from 1963 to 2012 predicts equallyweighted IR to be $31 \%$ from $2013-2017$ when actual IR is $26 \%$, and predicts value-weighted IR to be $20 \%$ when actual value-weighted IR is $17 \%$. Adding policy uncertainty, which is known to affect firm volatility (Baker, Bloom, and Davis, 2016), to the macroeconomic variables does not help reduce prediction errors.

In the second part of the paper, we focus on firm characteristics. Small and young firms are known to have much higher IR. High R\&D expenditures, high leverage, low profitability, and less liquidity are also associated with high IR. The recent literature has shown that the number of listed firms falls dramatically since the late 1990s, so that the number of listed firms in the United States is now less than in the 1970s

\footnotetext{
${ }^{1}$ In our analysis, firm-level IR is constructed from daily intra-month market model residuals (two other measures are also explored). For the aggregate results, we use both monthly equal-weighted and value-weighted averages across firms.
} 
(Doidge, Karolyi, and Stulz, 2016). Moreover, the listed firms in recent years are quite different from the listed firms in the 1990s (Doidge, Karolyi, and Stulz, 2016; Kahle and Stulz, 2017). Importantly, firms are larger, older, and more profitable; their common stock is more liquid. Such substantial and systematic changes in the characteristics of listed firms imply economically large decreases in IR relative to the late 1990s.

Since the characteristics of listed firms change dramatically over time, we use a novel approach to explain IR based on its link to firm characteristics. Specifically, we estimate models using the sample until 2012 and use the model slopes to predict idiosyncratic risk at the firm level from 2013 to 2017. We then average predicted firm-level IR to obtain average estimates of IR. This approach reflects the distribution of firm characteristics each month and hence takes fully into account changes in firm characteristics as long as the determinants of IR at the firm level are reasonably stable, which we show appears to be the case.

Using firm characteristics to explain firm-level IR and aggregating the results across firms explains the low recent IR much better than using only macroeconomic variables or using time-series regressions where the dependent variable is average IR and explanatory variables are macroeconomic variables and average firm characteristics. When we add lagged values of book/market, firm age, and firm size to a panel regression that has only lagged macroeconomic variables, predicted equally-weighted IR is $27 \%$ compared to actual IR of $26 \%$. With value-weighting, predicted IR and actual IR are both $17 \%$. In other words, firm characteristics can fully explain why value-weighted IR is so low in the recent past.

We examine how our results are consistent with evidence that market risk is not historically low in recent years. If IR falls but market risk does not, it must be that stock returns become more correlated with the market. Large firms have higher market-model R-squareds. Hence, changes in firm characteristics should also lead to an increase in R-squareds. In line with this prediction, we find that average R-squared from 2013 to 2017 is higher than in any year from 1963 to 2006.

The next section provides a summary of the related literature. Section 2 describes our data and construction of risk measures and other variables. Section 3 studies idiosyncratic risk over time. Section 4 investigates whether macroeconomic variables can explain the low recent IR. In Section 5, we show that 
firm characteristics have more explanatory power for IR than macroeconomic variables and that they can explain the low recent IR. Section 6 shows that market risk is not unusually low in recent years and that market model R-squareds have increased as expected given the changes in firm characteristics. Finally, Section 7 concludes.

\section{Literature on the Determinants of Idiosyncratic Risk}

Campbell, Lettau, Malkiel, and Xu (2001, hereafter CLMX) document that idiosyncratic risk more than doubles for the average public U.S. firm from 1962 to 1997 . More recently, researchers show that the increase in idiosyncratic risk reverses by 2003 (Brandt, Brav, Graham, and Kumar, 2010). Further, Bekaert, Hodrick, and Zhang (2012) find that extending the sample of CLMX to 2008 leads to the results that there is no trend in IR and that IR is well described "by a stationary autoregressive process that occasionally switches into a higher-variance regime that has relatively short duration" (p. 1155).

Since CLMX, much research attempts to explain the high IR of the end of the 1990s and the previous increase in IR. The leading explanations advanced in the literature are:

a. Increase in competition. This explanation advanced by Comin and Philippon (2005), Gaspar and Massa (2006), and Irvine and Pontiff (2009) predicts that idiosyncratic risk increases with competition.

b. R\&D. Comin and Philippon (2005) posit that an increase in R\&D expenditures leads to Schumpeterian destruction, which creates higher idiosyncratic risk at the firm level. Comin and Mulani (2009) propose a formal model.

c. Financial development. Chun, Kim, Morck, and Yeung (2008) advance the explanation that financial markets have become more developed, so that more private information is incorporated in stock prices. If more private information is incorporated in stock prices, stock returns should depend less on the market factor, and market-model R-squareds should fall. Brown and Kapadia (2007) attribute the increase in IR to the increased willingness of markets to welcome riskier IPOs, which they view as evidence of greater financial development. 
d. Institutional investors. Bennett and Sias (2006), Xu and Malkiel (2003), and Bennett, Sias, and Starks (2003) attribute the increase in idiosyncratic risk to increased institutional ownership.

e. Irrational exuberance. Brandt, Brav, Graham, and Kumar (2010) attribute the high idiosyncratic risk of the late 1990s to "an episodic phenomenon, at least partially associated with retail investors" (p. 863).

f. Young firms. Fink, Fink, Grullon, and Weston (2010) argue that changes in the age of listed firms explain most of the increase in IR. Bekaert, Hodrick, and Zhang (2012) build on this idea by using a model where idiosyncratic volatility depends on the fraction of young firms among listed firms.

g. Growth opportunities. Cao, Simin, and Zhao (2008) posit that in the presence of growth options, shareholders have incentives to take the riskiest projects. Controlling for growth options, they conclude that there is no trend in IR.

h. Profitability. Wei and Zhang (2006) show that firm stock volatility is negatively related to return on equity (ROE). They find that the upward trend in average stock return volatility is fully accounted for by a downward trend in ROE and by an upward trend in the volatility of ROE.

i. Macroeconomic factors. Bekaert, Hodrick, and Zhang (2012) find that most of the time variation in IR can be accounted for by variation in growth opportunities, market volatility, and the variance premium, which they argue is a business cycle sensitive risk indicator. Fox, Fox, and Gilson (2016) find that IR increases dramatically during crisis periods.

At the firm level, Pástor and Veronesi (2003) show how investor uncertainty about firm profitability is an important determinant of idiosyncratic risk and firm value. Recent work also analyzes differences in idiosyncratic risk (as well as market risk and R-squared) across firms and countries (e.g., Bartram, Brown and Stulz, 2012).

Our paper is also related to a developing literature on how uncertainty affects individual firms. Baker, Bloom, and Davis (2016) show that policy uncertainty increases firm stock return volatility. Using structural models, Bloom et al. (2012) and Bachmann and Bayer (2012, 2013) show that uncertainty shocks 
generate drops in output due to their effect on investment and labor, and empirical studies also show evidence of a negative relationship between uncertainty and investment (see, e.g. Gilchrist, Sim, and Zakrajsek, 2014; Kellogg, 2014; Bloom et al., 2007; Guiso and Parigi, 1999; Leahy and Whited, 1996). At the same time, uncertainty appears to increase research and development spending (Stein and Stone, 2012). Firms with more growth opportunities also have cash flows with longer duration, which is positively related to their level of firm-specific risk (Dechow, Sloan, and Soliman, 2004).

The development of the literature on the determinants of IR is largely due to an effort to understand the increase in IR that culminated in the extremely high IR at the turn of the century. We add to this literature by uncovering the unusually low IR in recent years and exploring it to test the validity of previously proposed IR determinants. We also use the low recent IR to assess how the dramatic changes in the number and composition of listed firms affect the risk profile of listed firms.

\section{Data and Construction of Risk Measures and Explanatory Variables}

Our sample includes all publicly traded U.S. firms for the period January 1963 through June 2017. We use daily data on individual stock returns and market returns from CRSP as well as quarterly and annual accounting data and firm characteristics from Compustat. Appendix A defines all the variables used in our analysis. We limit our analysis to common stocks (CRSP share codes 10 and 11) listed on the NYSE, AMEX, or Nasdaq. We exclude micro-cap stocks by dropping firms that are in the bottom $20 \%$ of the distribution of NYSE market capitalization (using one-month lagged values) as well as penny stocks with prices less than $\$ 1.00$ (in January 1997 dollars), in order to avoid concerns that microstructure frictions and tiny stocks confound our tests. However, we have also implemented all our tests using all stocks available and find that most of our inferences are similar (we discuss in the text when they are different). This is not surprising as the correlation between the equally-weighted IRs for the two samples is 0.96 and for the valueweighted IRs is 0.99 . Our final sample covers an average of $92.9 \%$ of the market capitalization of all stocks with available data on CRSP. Coverage is only an issue for a few years early in our sample period (1963- 
1966) when Compustat coverage is relatively poor. Since 1966 our sample covers an average of $95.6 \%$ of total market capitalization.

We use three methods for defining idiosyncratic risk and market risk. Our first method is based on standard market-model regressions to allow for monthly firm-specific measures of risk following the literature. Specifically, using daily data, we estimate (for each firm and month in our sample) the model

$$
R_{i, t}=\alpha_{i}+\beta_{i} R_{M, t}+\varepsilon_{i, t}
$$

where $R_{i, t}$ is firm $i$ 's stock return (in excess of the risk-free rate) on day $t$, and $R_{M, t}$ is the return on the CRSP value-weighted market index (in excess of the risk-free rate) on day $t$. Our estimate of idiosyncratic risk of firm $i$ is the (annualized) standard deviation of the regression residual $\varepsilon_{i, t}$, and our estimate of market risk of firm $i$ is $\beta_{i}$ times the (annualized) standard deviation of $R_{M, t .}$. We estimate the market model for all firmmonths with at least 15 daily return observations available in CRSP and drop any firm-month with idiosyncratic risk less than 0.001 . Estimating this model monthly for all stocks provides a panel of volatility estimates across firms and months as well as aggregated time-series of market and idiosyncratic risk by averaging the respective firm-level measures by month, alternatively using equal- and value-weighting.

Our second method utilizes the approach of CLMX to create aggregated time-series for market risk and idiosyncratic risk for all firms. Daily data are used to construct monthly observations for each month. Our third method uses daily observations for the five factors of the Fama French (2015) model (i.e., the excess return on the market, SMB, HML, RMW and CMA), which are available since July 1963 from the Ken French data library. ${ }^{2}$ Similar to the estimation of the market model, we regress the daily excess stock return of each firm on the five factors in each calendar month and obtain firm-specific measures of idiosyncratic risk as the annualized standard deviation of the regression residuals. As an alternative to the use of daily returns, we also construct all three measures of idiosyncratic risk using daily series of overlapping 5-day returns.

${ }^{2}$ The data is available at http://mba.tuck.dartmouth.edu/pages/faculty/ken.french/index.html. 
For macroeconomic variables other than market risk (which we measure by averaging firm-level market risk from the market model or CLMX model), we use the credit spread (Credit Spread) defined as the difference between Moody's seasoned Baa corporate bond yield and the 10-year U.S. Treasury constant maturity rate, both provided by the Board of Governors of the Federal Reserve System. We source the S\&P 500 volatility index (VIX Index), starting in 1986, from the CBOE website. NBER business cycle dates are from the NBER website. The Chicago Fed National Activity Index (Chicago Fed Index) is sourced from the Federal Reserve Bank of Chicago website. The value-weighted stock market return is from CRSP (CRSP VW-Return). We obtain the quarterly uncertainty index (Uncertainty Index) for the United States over the period 1968-2011 from Kozeniauskas, Orlik and Veldkamp (2014). This index is an index of ex ante conditional volatility for GDP. We also use the monthly index of U.S. economic policy uncertainty (Economic Policy Uncertainty Index) covering 1985-2017 from Baker, Bloom, and Davis (2016). This index uses newspaper text analysis, the number of expiring tax laws, and forecast dispersion. ${ }^{3}$

We construct inflation-adjusted market capitalization (Real Market Capitalization) by multiplying market capitalization from CRSP (constructed by multiplying share price with the number of shares outstanding) with the ratio of the All-items Consumer Price Index (CPI) of the month to the CPI of the base period (from Federal Reserve Economic Data (FRED)) using January 1997 as the base period. The age of the firm is measured as the difference in years between the observation date and the date of the first price on CRSP (Firm Age). As a measure of illiquidity, we calculate the Amihud (2002) illiquidity measure (Illiquidity Ratio) for each firm and month in our sample by taking the average of daily absolute stock returns divided by dollar volume. Poor liquidity in some stocks could cause asynchronous price movements that would affect our regression estimates.

\footnotetext{
${ }^{3}$ The data is available at www.PolicyUncertainty.com.
} 
For our firm-level analysis we combine data from CRSP and Compustat. We define monthly values for firm-level accounting variables of interest by using the most recent quarterly/annual values, dropping observations for which Compustat data are unavailable. ${ }^{4} \mathrm{We}$ calculate the book/market ratio as the ratio of the sum of common equity and balance sheet deferred taxes to market capitalization (Book/Market). Financial leverage (Leverage) is measured as the sum of total debt plus preferred stock divided by the market value of the firm's assets (calculated as the sum of market capitalization, preferred stock and total debt). We also calculate the ratio of capital expenditures to total assets (Capital Expenditures/Total Assets) and the ratio of research and development (R\&D) expenses to total assets ( $R \& D$ Expenses/Total Assets), setting missing values of capital expenditures and $R \& D$ expenses to zero. We use the natural logarithm of one plus the ratio of the sum of cash and short-term investments to total assets (Cash and Short-term Investments/Total Assets). Return on equity $(R O E)$ is calculated as the ratio of net income to shareholders' equity. Following Kahle and Stulz (2017), we use sales data at the 3-digit NAICS code level (using historical classifications where available) to construct a Herfindahl index to measure the degree of competition (Revenue Herfindahl). Using data from Compustat on index constituents starting in March 1964, we construct an indicator variable for whether a stock is in the S\&P 500 index or not ( $\& \& P$ Constituent). We use quarterly data on institutional ownership from Thomson Reuters to capture the fraction of shares outstanding owned by institutional investors (Institutional Ownership); these data start in March 1980.

\section{Idiosyncratic Risk over Time}

Figure 1 plots our time-series estimates of average IR. Panel A shows the equally-weighted measures, and Panel B shows the value-weighted measures. It is immediately clear from both Panels that, irrespective of how IR is estimated, the IR estimates in the last five years are extremely low. The only estimates that are lower than the lowest values of the last five years are in the 1960 s.

\footnotetext{
${ }^{4}$ We sum quarterly flow variables over the most recent four quarters. We combine annual and quarterly accounting data by replacing missing values in the $4^{\text {th }}$ quarter with the respective annual observation. We replace missing values in other fiscal quarters with prior observations from fiscal quarters in the same fiscal year or the $4^{\text {th }}$ quarter from the prior fiscal year. Results are robust to using only annual accounting data.
} 
Figure 1 shows clearly that IR is extremely high towards the end of the 1990s and in the early 2000s. There are two other periods with comparably elevated IR. The first period is during and immediately after the market crash of 1987. The second period corresponds to the period following the bankruptcy of Lehman in 2008. The figure also shows that, especially for equally-weighted IR, IR is elevated compared to historical values for much of the 1990s. Looking at the Figure from the late 1970s to the early 2000s, an upward trend is quite apparent. However, after 2000, IR falls steadily until the global financial crisis (GFC), so that immediately before the credit crisis it has extremely low values. In fact, the lowest values before the GFC are not observed since the mid-1970s. Obviously, IR increases dramatically with the GFC before falling again and at times taking values that are not observed since the 1960s. The fact that IR increases sharply in crises obscures the fact that outside crises and recessions, IR is quite low already before the GFC. The changes in firm composition discussed in the introduction start before the GFC.

Figure 1 shows clearly that IR after the crisis is unusually low irrespective of the estimation method and irrespective of whether we use an equally-weighted measure or a value-weighted measure. We now examine whether IR is unusually low in the recent past more formally. In Table 1, we show estimates of regressions of measures of IR on indicator variables for each five year period since 1963. The most recent period of 2013-2017 is the omitted period, so that the coefficients show how IR for each five-year period compares to the most recent period.

The first column of Panel A of Table 1 gives regression estimates when we use the equally-weighted IR built from market model residuals. We see that IR is higher in each five-year period than in the last period except for the first period where it is significantly lower. Not surprisingly, IR during the period 19982002 is considerably higher. The second column shows regression estimates when IR estimates are obtained from the CLMX model. The same conclusion applies except that now the IR over the recent period is not higher than the IR of the first five-year period. The third column uses IR estimates from the Fama-French five-factor model. The results are similar to those obtained with the CLMX approach. The next three columns in Table 1 show estimates for value-weighted measures of IR. With these measures, no five-year 
period has lower IR than the most recent period. All but the first five-year period have significantly higher idiosyncratic volatility than the most recent period.

One issue with the long sample period we use is that it combines data from the NYSE since 1963 with data for Nasdaq, which becomes available in 1973. Hence, from 1963 to 1972, we only have NYSE data, and afterwards we have data from both exchanges. It is well-known that the Nasdaq firms tend to be smaller, younger, and more technologically oriented. Further, much of the dot-com frenzy of the late 1990s took place on Nasdaq. These considerations suggest that it is important to check whether the results differ if we look at the exchanges separately. Panel B of Table 1 shows estimates for the NYSE. For the whole Panel, all coefficients are significantly positive except for six coefficients. With the market-model approach, the periods 2003-2007 (with equal weighting) and 1963-1967 do not have significantly higher idiosyncratic risk than the recent period. When using the CLMX approach, the first period has insignificant coefficients. With the Fama-French five-factor model, the first period has an insignificant coefficient for the equallyweighted estimate of IR, but the coefficient is significantly positive for the value-weighted estimate of IR. When we turn to Nasdaq, all coefficients are significantly positive except two, namely the coefficients for equally-weighted IR in 1978-1982 when we use the market model or the CLMX model. It follows that our conclusions hold up for each exchange separately.

An obvious concern is that our results might be different if we use different five-year periods or shorter or longer periods. We re-estimate the regressions of Table 1 on indicators for calendar years from 1963 to 2012. We do not put the results in a table as they are unwieldy. With this regression model, the coefficients on indicator variables indicate whether IR in any one year is significantly different from IR over the period 2013-2017. Almost all coefficients are significantly positive. Exceptions are not surprising. First, all coefficients but one from 1963 to 1965 are significantly negative. Second, all coefficients in 2012 are insignificant and most coefficients in 2010 are insignificant. Coefficients for value-weighted IR measures from 2004 to 2006 are mostly insignificant. Finally, a majority of the coefficients are not significant in 1977 and in 1966. The bottom line from these estimates is that IR is only significantly lower than in recent years in the first three years at the beginning of the sample. From 2004 to 2006 and from 2010 to 2012, there are a 
number of insignificant coefficients indicating that IR is not significantly higher in those years for some measures.

In summary, irrespective of the measures we use, there is strong evidence that since 1963 the only years where IR is lower than in recent years is in the 1960s. This conclusion does not depend on the estimation method for IR.

\section{Can Macroeconomic Variables Explain the Low Idiosyncratic Risk in Recent Years?}

As Figure 1 shows and as has been shown in the literature, IR is high in crisis periods. This means that IR is related to aggregate developments in financial markets and in the economy as a whole. We call variables that proxy for aggregate developments in financial markets and in the economy as a whole macroeconomic variables. To explore how idiosyncratic volatility is related to macroeconomic variables, we first consider how it differs depending on the level of some macroeconomic variables that are plausibly related to idiosyncratic volatility. Except for the NBER recession indicator, we rank the observations of macroeconomic variables and split the sample in half between high and low values. Since market risk is a byproduct of our estimates of idiosyncratic risk, we also provide information on market risk.

The first macroeconomic measure we use in Table 2 is the volatility of the CRSP value-weighted market index. The risk measures we report are equally-weighted averages within a month, then averaged across the relevant months. Total risk is the average of the volatility of stock returns. Not surprisingly, total risk and market risk are high when CRSP volatility is high. However, we also see that IR is high when CRSP volatility is high. Our measures of market risk are high when CRSP volatility is high, which implies that IR and market risk are high together. This result is consistent with the evidence in Figure 1 that IR is high in crisis periods when market volatility is high. The next macroeconomic measure we consider is an indicator for NBER recessions. We find that market risk and IR are high in recessions. Another proxy of economic activity that is available monthly is the Chicago Fed National Activity Index. This index is high when the economy is doing well. We see that both market risk and IR are low when the economy is doing well. Credit spreads increase in recessions and in periods of crisis. We see that IR is higher when credit 
spreads are wider. VIX is a measure of ex ante uncertainty as it is based on implied volatilities. IR is high when the VIX index is high.

As already discussed, we use two uncertainty indices. These indices are available for shorter periods than our whole sample period. With the Uncertainty Index from Kozeniauskas, Orlik, and Veldkamp (2014), IR and market risk are high when uncertainty is high. This is not the case with the baseline Economic Policy Uncertainty Index from Baker, Bloom, and Davis (2016). With that index, market risk is high when the index is high, but IR is not. Though we do not tabulate the results, Baker, Bloom, and Davis (2016) also have an economic policy uncertainty index that is constructed from news only. If we use that index, IR is high when that index is high.

It follows from the results in Table 2 that IR is high when stock market volatility is high, when the economy is doing poorly, when credit spreads are wide, and when aggregate uncertainty is elevated. These results hold irrespective of the IR measure we use. We also explore whether these results hold similarly for sub-periods or conditioned on the exchange on which a firm is listed. We find that they do. To explore more formally how IR is related to macroeconomics variables, we follow the approach used in the literature of regressing average IR on macroeconomic variables. We call this approach the time-series regression approach to contrast it with the panel regression approach we use later.

We regress in Panel A of Table 3 our measures of IR on the macroeconomic variables. Because the uncertainty measures are not available for the whole sample period, we exclude them from the regressions reported in Table 3 and discuss results using these measures separately. For all three measures of IR, we see a strong positive coefficient for market risk, so that IR is high when market risk is high. ${ }^{5}$ IR is also high during recessions. Neither the Chicago Fed Index nor the CRSP valued-weighted return have significant coefficients for the market-model measure. With the CLMX measure and for value-weighted IR from the five-factor Fama-French model, the CRSP value-weighted return is significant with a positive coefficient.

\footnotetext{
${ }^{5}$ Note that we use the market-model market risk measure for the regressions using the Fama-French model for idiosyncratic volatility as that measure captures the risk associated with market exposure.
} 
Though we do not tabulate the results, we estimate the regressions over the period for which the uncertainty indices are available. We find that the Uncertainty Index has a significant positive coefficient in all the regressions of Panel A of Table 3. When we use the Economic Policy Uncertainty Index instead, we find that the Index is significant for equally-weighted IR but not for value-weighted IR.

In Panels B and C, we estimate different specifications for the regressions. First, in Panel B, we reestimate the regressions but add lagged variables. The explanatory power of the regressions is little affected by the addition of the lagged variables, and most lagged variables are insignificant. The notable exception is for credit spreads, as well as for market risk when the idiosyncratic risk measure uses the CLMX approach. In that case, the lagged market risk measure is significant. Lagged market risk is also always significant in regressions with value-weighted risk measures. When we re-estimate the regressions in Panel B with the uncertainty indices, the coefficients on the indices are never significant. Second, in Panel C, we estimate the regression without lags but in changes. With the change regressions, the coefficients on market risk and credit spreads are consistently positive and significant at the $1 \%$ level. The NBER recession coefficient is not significant, but now the Chicago Fed Index is significant in some of the models and the CRSP value-weighted return is significant. We cannot look at monthly change regressions with the Uncertainty Index because it is only available quarterly. With the Economic Policy Uncertainty Index, we find significant coefficients except for value-weighted IR constructed using the Fama-French five-factor model.

To investigate whether macroeconomic variables explain the low IR of recent years, we proceed as follows. We estimate the model in Table 3, Panel A, that uses equally-weighted idiosyncratic risk from the market model, for the period 1963-2012. We then use the estimated model to predict IR for the period 20132017 using actual values for the macroeconomic variables. As reported in Table 4, we find that the average actual IR over that period is $26.26 \%$. The predicted IR for the same period using regression "out-of-sample" prediction is $31.39 \%$, which is lower than the actual historical average from 1963 to 2012 of $34.67 \%$, so that the macroeconomic model improves the prediction of the level of average IR relative to using the 
historical average. The difference between the actual average IR and the predicted average IR is 5.13 percentage points, and it is significant at the $1 \%$ level. The negative difference means that the model using aggregate variables over-predicts IR. It does so substantially, as predicted IR is $20 \%$ higher than actual IR.

We repeat the exercise for value-weighted IR. Actual value-weighted IR is $16.87 \%$ while predicted IR is $19.76 \%$. The difference between actual and predicted is -2.89 percentage points, and it is significant at the $1 \%$ level. The estimated model over-predicts value-weighted IR by $17 \%$. It follows that the macroeconomic variables we consider cannot explain why IR is so low over the last five years. We cannot conduct this type of analysis with the Uncertainty Index because it does not cover the period 2013-2017, but we can do so with the Economic Policy Uncertainty Index. The average prediction error is not materially different when we add the Economic Policy Uncertainty Index to the model.

\section{$5 \quad$ Firm Characteristics and Low Idiosyncratic Risk}

In this section, we show how firm characteristics differ in the recent past from their values at the end of the 1990s. We then show in panel regressions how firm-level IR relate to firm characteristics. Finally, we use panel regressions to predict firm-level IR and aggregate the predicted values of firm-level IR to show that firm characteristics can explain the recent low values of IR.

\subsection{Changes in Firm Characteristics}

It is well-known that firm characteristics are related to idiosyncratic risk. In particular, young firms and small firms are expected to have higher idiosyncratic risk (see Pástor and Veronesi, 2003). Illiquid firms tend to have higher idiosyncratic risk. Firms with higher R\&D have higher idiosyncratic risk (Comin and Philippon, 2005, and Bartram, Brown, and Stulz, 2012). As Kahle and Stulz (2017) show, firm characteristics change considerably since the 1990s for listed firms, partly as a result of the drop in the number of listed firms and partly as a result of changes in what firms do and how they do it. Doidge, Karolyi, and Stulz (2016) and Kahle and Stulz (2017) find that U.S. listed firms have become much larger and older since the 1990s. Both of these evolutions are expected to lead to a decrease in idiosyncratic risk. In this section, we first provide evidence on how firm characteristics differ in the recent period compared to the 
late 1990s. We then show that firm characteristics are much better than macroeconomic variables at helping us understand why IR is low.

Table 5 compares mean and median firm characteristics for the period 1996-2000 to firm characteristics for the period 2013-2017. The first three rows show data for firm-level idiosyncratic risk. Not surprisingly, there is a large drop in idiosyncratic risk. The drop is roughly similar across the idiosyncratic risk measures, ranging from $44 \%$ for the market model measure to $47 \%$ for the CLMX measure. Book/market is not significantly different across the two periods. Though leverage falls, the change is economically insignificant. The illiquidity measure exhibits an extremely large decrease. It falls by a factor of two. Capital expenditures fall. $R \& D$ expenses to assets fall as well, but the fall is economically trivial. Not surprisingly in light of the literature, cash holdings are higher now (see Bates, Kahle, and Stulz, 2009). Firms are substantially older as mean age increases from 14 years to 23 years. Firms have also become much larger. The mean return on equity (ROE) increases. As discussed in the literature, one explanation advanced for greater idiosyncratic volatility is greater competition. The average Herfindahl index computed from revenues increases substantially, which is consistent with a decrease in competition and hence a decrease in idiosyncratic volatility according to the literature. Finally, not surprisingly, a firm is more likely to be a S\&P 500 index constituent, because there are fewer listed firms, and has more institutional ownership as average institutional ownership increases substantially (by roughly 50\%).

\subsection{Using Firm Characteristics to Explain Idiosyncratic Risk}

To assess how firm characteristics help explain idiosyncratic risk, we add lagged firm characteristics individually to a regression that has lagged macroeconomic variables. We lag all variables by one month to reduce concerns about a feedback effect from idiosyncratic volatility to firm characteristics. We show the estimates in Panel A of Table 6. We present results for the whole sample and for the second half of the whole sample, 1983-2017. By looking at results for the second half of the sample, we can assess the stability of the coefficients. We omit the coefficients on the macroeconomic variables (we show these coefficients in Panel B). We use the same macroeconomic variables as in Table 3, except that for market risk we use 
firm-level market risk from the market-model. If we estimate a regression with only the macroeconomic variables (reported in Panel B), the adjusted R-squared is 7\%. All firm characteristics have significant coefficients, and the coefficients are quite similar for the whole sample and for the second half of the sample. We cluster standard errors by firm and month.

As shown in Row 1 of Panel A of Table 6, idiosyncratic risk increases with illiquidity. The adjusted Rsquared is $20 \%$ when we add illiquidity to the macroeconomics variables, so that the incremental explanatory power of illiquidity is higher than the explanatory power of all macroeconomic variables combined. Not surprisingly, idiosyncratic risk falls with market capitalization and with age. Market capitalization is the variable that adds the most explanatory power to the regression with only macroeconomic variables. Age adds as much explanatory power as illiquidity. The firm characteristics that have positive coefficients are illiquidity, capital expenditures, R\&D expenditures, cash holdings, and the industry Herfindahl index. In contrast, idiosyncratic risk is negatively related to market capitalization, age, book/market, leverage, ROE, S\&P inclusion, and institutional ownership. It is noteworthy that the coefficients on the Herfindahl index and on institutional ownership are inconsistent with explanations advanced in the literature for the high IR of the late 1990s. A higher Herfindahl index means lower competition, but here lower competition is associated with higher idiosyncratic risk. We also see that institutional ownership is negatively related to idiosyncratic risk.

The adjusted R-squared for the macroeconomic variables combined is $7 \%$. Four firm characteristics individually increase the adjusted R-squared by the same amount as all macroeconomic variables together. These characteristics are in order of increase in adjusted R-squared, market capitalization, illiquidity, age, and profitability. From Table 5, we know that these variables change significantly from the late 1990s to the recent period in the direction that predicts decreases in idiosyncratic risk, i.e. firms in 2013-2017 are larger, older, more profitable and more liquid than before. Hence, given the evolution of the firm characteristics that have the most explanatory power in forecasting idiosyncratic risk, we would expect IR to be lower in the recent period. 
An issue with Panel A of Table 6 is that many firm characteristics are correlated, and in some cases highly so. We now turn to multiple regressions to assess how our inferences about the relation between idiosyncratic risk and firm characteristics is affected when we include multiple firm characteristics in regressions. Panel B of Table 6 shows estimates of panel regressions that include all firm characteristics. As in Panel A, we show results for the whole sample period and for the second half of the whole sample period. We again lag variables and cluster standard errors by firm and month. The first three regressions are for the whole sample period. Regression (1) includes only lagged macroeconomic variables. The next regression, Regression (2), only uses firm characteristics. We include all of the firm characteristics of Panel A except the Herfindahl index, the S\&P constituent indicator, and institutional ownership. Comparing the estimates of coefficients on firm characteristics to those of Panel A, we find that most coefficients have the same sign, but their magnitude differs. The exception is the coefficient for leverage, which is positive and significant in Regression (2) of Panel B, but is negative and significant in Regression (1) of Panel A. The adjusted R-squared of Regression (2) of Panel B is $28 \%$, which is four times the adjusted R-squared of Regression (1).

In Regression (3), we include both macroeconomic variables and firm characteristics. The adjusted Rsquared increases to $35 \%$. Adding the macroeconomic variables to firm characteristics has almost no impact on the coefficients on the firm characteristics. The credit spread is no longer significant when we use firm characteristics. Regressions on the right hand side of the panel repeat Regressions (1) to (3) but use the second half of the sample. The explanatory power of the regressions is roughly the same across the two samples; the estimated coefficients on the firm characteristics are also largely similar.

One might argue that illiquidity is not a firm characteristics in the sense of a balance sheet or a performance variable and that it is directly affected by idiosyncratic risk as higher idiosyncratic risk can increase market-making costs. To assess the role of illiquidity in our results, we re-estimate our regressions omitting illiquidity. Doing so has no impact on the explanatory power of the regressions. It does affect the economic magnitude of the coefficient on size as it doubles in absolute value. 
Though we do not tabulate the results, we also estimate the regressions with firm-level institutional ownership as well with an indicator variable for S\&P 500 index inclusion. Stocks that are S\&P 500 indexconstituents have higher idiosyncratic volatility. However, in Panel A where we just add the indicator variable to the macroeconomic variables, stocks in the S\&P 500 index have significantly lower idiosyncratic volatility. These contradictory results are not surprising as firms belonging to the index tend to be larger and older firms and hence would be expected to have lower idiosyncratic volatility if one does not control for size and age. When we include all firm characteristics, there is no relation between idiosyncratic volatility and institutional ownership. In contrast, if we only add institutional ownership to the macroeconomic variables, institutional ownership has a significant negative coefficient. None of these results are consistent with the argument that institutional ownership is positively related to IR.

The regressions we tabulate do not include the Herfindahl index as we want to focus on firm characteristics and the Herfindahl index is an industry characteristic. When we estimate Regressions (2) and (3) in Panel B for both sample periods including the Herfindahl index, the coefficient on the Herfindahl index is positive and significant in all regressions. The estimated coefficients are similar to the coefficients in Panel B, but adding the Herfindahl index has no impact on the adjusted R-squared. These coefficients are difficult to reconcile with explanations for high IR that emphasize greater competition.

We show that, over our sample period, firm characteristics explain idiosyncratic risk better than macroeconomic characteristics in panel regressions. Further, we see that the relation between firm-level idiosyncratic risk and firm characteristics is similar for the whole sample period and the second half of the whole sample period. In Panel C, instead of using panel regressions, we use time-series regressions and regress average IR on lagged macroeconomic variables and firm characteristics. The firm characteristics in the regressions for a given month are equally-weighted averages of the characteristics of firms in the sample for the month. As in Panel B, the first three regressions are for the whole sample and the last three are for the second half of the whole sample.

Regression (1) uses only macroeconomic variables. All variables are significant except for the Chicago Fed Index. The adjusted R-squared of the regression is $20 \%$. Regression (2) uses only averages of firm 
characteristics. The adjusted R-squared when we use only firm characteristics is an extremely high $64 \%$. It is noteworthy that some of the regression coefficients on firm characteristics are quite different in the timeseries regression from the panel regression. In particular, illiquidity and cash holdings have significant negative coefficients in Panel C, but significant and positive coefficients in Panel B. When we include both macroeconomic variables and firm characteristics, the coefficient on illiquidity switches sign, but it is not significant. Leverage is no longer significant either. However, cash holdings still has a significant negative coefficient. The adjusted R-squared of Regression (3) is 74\%. The fact that the adjusted R-squared increases so little when we add the macroeconomic variables is due to the fact that in the time-series mean firm characteristics and macroeconomic variables are correlated.

The right side of the Panel repeats the estimations for the second half of the sample period. The only coefficient that is significant over the whole sample period in Regression (1), but is not over the second half period, is the credit spread. However, the adjusted R-squared is $17 \%$ for the second-half period instead of $20 \%$ for the whole period. While the explanatory power of macroeconomic variables is lower in the second-half period, the explanatory power of firm characteristics is higher. Regression (2) shows the adjusted R-squared for the regression with only firm characteristics is $72 \%$ for the second-half period. In the second-half period, several coefficients change sign or become insignificant. The coefficient on illiquidity is now positive as expected, but firm size has a positive significant coefficient. When we add the macroeconomic variables, the coefficient on firm size is not affected. It follows from this that, while for the panel regressions the coefficients seem fairly stable between the whole sample and the second-half of the whole sample, this is not so for the time-series regressions. In fact, some of the coefficients on firm characteristics are hard to reconcile with what is known about the determinants of IR. In particular, it is well-established that IR falls with firm size.

We also estimate regressions with the uncertainty indices but do not tabulate the results. Specifically, when we add the uncertainty indices to the panel regressions with all macroeconomic variables and all firm- 
level variables, the Uncertainty Index never has a significant coefficient and the Economic Policy Uncertainty Index has a negative significant coefficient. Neither uncertainty index has a significant coefficient for the time-series regressions.

\subsection{Prediction Errors}

Using the panel regression approach or the time-series approach, we can evaluate whether changes in explanatory variables can help understand the lower IR of recent years. One way to do so is to use the regression coefficients estimated over the whole sample period and investigate how the changes in firm characteristics shown in Table 5 affect IR. Using the average firm characteristics from Table 5 and specification (2) from Panel b of Table 6, we find that IR should fall by 6.6 percentage points from 1996-2000 to 2013-2017 with the 1963-2017 sample and by 6.9 percentage points with the 1983-2017 sample. When we use specification (2) of Panel C of Table 6, IR falls by 13.5 percentage points with the 1963-2017 sample and by 15.9 percentage points with the 1983-2017 sample. With the panel regression, the largest economic effect is for the change in market capitalization, as it implies a drop in IR of 3.7 percentage points for the whole sample and of 2.9 percentage points when we use the second half of the sample. Firm age is the firm characteristic whose change has the second most important economic significant and illiquidity is the third. All the other firm characteristics have small economic effects. When we turn to the time-series models, since the regression coefficients change a lot between the two samples, it is not surprising that the economic significance of the firm characteristic changes depends on the estimation period. As an extreme example, the change in firm size explains a drop in IR of 11.4 percentage points using the whole sample and an increase in IR of 9.5 percentage points using the second half of the sample.

A more exacting test of the role of firm characteristics is to investigate whether a model estimated before 2013 can predict IR during the 2013-2017 period using the actual values for the explanatory variables. To do so, we proceed as follows: We estimate our regression models of Panels B and C of Table 6 for periods ending in 2012. We then use the estimated regressions to predict IR during the 2013-2017 period using the actual values for the explanatory variables. We report the results in Table 7. 
Panel A of Table 7 shows results when we use panel regressions and equally-weighted IR estimates. In other words, for each month from 2013 to 2017, we forecast each firm's idiosyncratic volatility using the regression estimated until 2012 and lagged explanatory variables for that month. We then average the predicted IR estimates for each month and compare the predicted IR to actual IR. We show results in the first four rows using 1963-2012 to estimate the regression and in the next four rows using 1983-2012 instead. Using only macroeconomic variables, the mean predicted IR is $32.0 \%$ in contrast to the actual mean of $26.1 \%$. Consequently, the model's forecast is $23 \%$ higher than the actual IR. We turn next to a model that adds book/market, market capitalization and age to Model (1). The results are shown in Model (2). The predicted IR falls to $27.5 \%$. The average prediction error is now $5 \%$, but it is still significantly different from zero. Model (3) is a model with only firm characteristics. It uses all the firm characteristics used in Regressions (2) of Panel B of Table 6. The average predicted IR is $28.3 \%$, which is $9 \%$ higher than actual volatility. If we add illiquidity, the results are the same. If we use both macroeconomic and firm variables, the average prediction error is $8 \%$. The results using the estimation period of 1983-2012 are similar to those using the longer estimation period.

When we turn to the value-weighted results, the model with only macroeconomic variables predicts mean IR of $31.4 \%$ when actual idiosyncratic volatility is $16.8 \%$. This means that the forecast is too high by $86 \%$. When we add book/market, market capitalization and age to Model (1), we find that the prediction error is only -0.03 , and it is insignificant. The same results hold if we add illiquidity. With all firm variables, predicted IR is too high by $8 \%$. With both macroeconomic and firm variables, the prediction error drops to 4\%. It follows from these results that models with firm characteristics perform much better in predicting the level of value-weighted IR. The value-weighted results using 1983 to 2012 to estimate the model are also very similar.

We now turn to results using time-series models. The time-series models perform much better for valueweighted IR than for equally-weighted IR. The results are shown in Panel B. For equally-weighted IR, Model (1), which uses only macroeconomic variables, over-predict substantially actual IR. Model (2) adds to the regression average book/market, market capitalization and age. When we add these firm-specific 
variables, the prediction error changes sign, but the absolute value remains similar. Model (3) uses all firm characteristics but no macroeconomic variables. The prediction error falls by half. Finally, when we use the macroeconomic variables and all firm characteristics, the prediction error is 0.039 , which is quite close in absolute value to the prediction error of -0.048 when we do not use firm characteristics. The results using the shorter sample period to estimate the regression models have one important difference, namely the prediction error of the model using only firm characteristics becomes insignificant. When we turn to the value-weighted model, we see that the purely macroeconomic model over-predicts, but much less so than when we use panel regressions. In Model (2), the prediction error is insignificant. The over-prediction falls from $19 \%$ to $4 \%$ when we use all firm variables and no macroeconomic variables. With both macroeconomic variables and firm variables, the model under-predicts actual IR by 7\%. Results for the models estimated from 1983 to 2012 differ in that model (2) now has a large average prediction error, while model (3) has an insignificant average prediction error.

We repeat this analysis using the sample of all firms with available data rather the sample that excludes micro-caps. The results using the panel regressions yield insignificant prediction errors for model (2) for both estimation sample periods for equally-weighted IR and for model (3) for both sample periods for valueweighted IR. Overall, there are more cases where the average prediction error is insignificant when we use all firms. For the time-series regressions, the value-weighted results are very similar, but model (3) for equally-weighted IR estimated from 1983 to 2012 has a significant average prediction error.

It follows from this section that using firm characteristics predicts a significant drop in IR from the late 1990s to the recent past and improves predictions of the level of IR in recent years so that some models with firm characteristics yield an insignificant prediction error. Moreover, the relation between firm characteristics and IR is much more stable in a panel regression than the relation between aggregate measures of firm characteristics and IR. With firm characteristics and panel regression estimates, prediction errors for value-weighted IR from a parsimonious model with firm characteristics are insignificant irrespective of the period used to estimate the regression model. 


\section{Changes in Firm Characteristics, Market Risk, and R-squareds}

Using market risk and macroeconomic variables to forecast idiosyncratic risk in recent years produces forecasts that are too high. One way to state this is that IR is low given market risk. Figure 2 shows the plot of the market model equally-weighted IR and market risk. While IR is low in recent years, market risk is not especially low.

In Panel A of Table 8, we regress market risk on indicator variables for five-year periods. The table is the same as Table 1 except we use market risk instead of idiosyncratic risk. We have ten indicator variables. Market risk is higher than in the most recent period (captured by the regression intercept) in only two fiveyear periods for the regressions using equally-weighted market risk estimates and three in the regressions that use value-weighted results. For the equally-weighted results, there are seven periods with the market model where the equally-weighted market risk is lower than in the most recent period, and one with the CLMX model. For value-weighted market risk, there is only one period where market risk is significantly lower.

The changes in firm characteristics we have focused on include firms becoming larger and older. For instance, Bartram, Brown, and Stulz (2012) show that market-model R-squareds increase in firm size, age, cash holdings, and liquidity. Since the 1990s, firms have become larger, older, hold more cash, and are more liquid. Hence, we would expect market-model R-squareds to have increased. To investigate this, we estimate regressions of average R-squared on indicator variables for five-year periods. We show the results in Panel B of Table 8. The results are very strong. Average R-squared is high compared to all previous periods except for the period from 2008 to 2012 using equally-weighted R-squared, and it is high compared to all previous periods except from 2003 to 2012 using the value-weighted R-squared.

\section{Conclusion}

We show in this paper that idiosyncratic risk has not been as low as in recent years since the early 1960s. Though the 2013-2017 period we focus on is a period without a recession or a financial crisis, macroeconomic variables predict significantly higher idiosyncratic volatility than actual idiosyncratic volatility 
during that period. We find that the historically low IR can be explained by the changes in firm characteristics that take place since the 1990s.

Since the late 1990s, the number of listed firms has fallen dramatically and the composition of listed firms has changed considerably, with public firms becoming larger and older. We show that there is a stable relation between firm-level idiosyncratic risk and firm characteristics. In our panel regressions, we find no evidence that IR increases with institutional ownership, and we find that IR increases rather than falls when an industry becomes more concentrated. These results suggest that explanations advanced for the high IR of the late 1990s that focus on increased institutional ownership and increased competition cannot help in understanding the dynamics of IR more generally. However, while firm characteristics are helpful in understanding the dynamics of IR in normal times, our study does not address the puzzle that IR can become extremely large in crises or unusual times, a puzzle that parallels the puzzle of market volatility exhibiting such large movements as well (Schwert, 1989).

The stable relation between IR and firm characteristics can be used to forecast aggregate idiosyncratic risk during 2013-2017 fairly well. Specifically, models estimated over 1963-2012 or 1983-2012 with only macroeconomic variables always substantially overpredict equally-weighted and value-weighted IR when using realized macroeconomic variables from 2013 to 2017 relative to models that use firm characteristics. In particular, a parsimonious model with firm characteristics has insignificant prediction errors over 20132017 when we predict value-weighted idiosyncratic risk one month ahead using a model estimated over 1963-2012 or over 1983-2012. These results show that, absent financial crises or irrational exuberance, idiosyncratic risk can be expected to be low because firm characteristics are much different from what they were when idiosyncratic risk was especially high in the late 1990s.

Our analysis implies that it is important to take into account the changes in the composition of public firms over the last twenty years when evaluating the risk profile of these firms. 


\section{References}

Amihud, Y., 2002, Illiquidity and stock returns: cross-section and time-series effect, Journal of Financial Markets 5, 31-56.

Bachmann, R., and C. Bayer, 2012, Investment dispersion and the business cycle, NBER, working paper.

Bachmann, R., and C. Bayer, 2013, Wait-and-see business cycles? Journal of Monetary Economics 60, 704-719.

Baker, S.R., N. Bloom, and S.J. Davis, 2016, Measuring economic policy uncertainty, The Quarterly Journal of Economics 131, 1593-1636.

Bartram, S.M., G.W. Brown, and R.M. Stulz, 2012, Why Are U.S. Stocks More Volatile? Journal of Finance 67, 1329-1370.

Bartram, S.M., G.W. Brown, and R.M. Stulz, 2016, Why does idiosyncratic risk increase with market risk? unpublished working paper.

Bates, T., K. Kahle, and R.M. Stulz, 2009, Why Do U.S. Firms Hold So Much More Cash than They Used To? The Journal of Finance 64, 1985-2021.

Bekaert, G., R.J. Hodrick and X. Zhang, 2012, Aggregate Idiosyncratic Volatility. Journal of Financial and Quantitative Analysis 47, 1155-1185.

Bennett, J. R. Sias, and L. Starks, 2003, Greener Pastures and the Impact of Dynamic Institutional Preferences, Review of Financial Studies 16, 1203-1238.

Bennett, J., and R. Sias, 2006, Why Company-Specific Risk Changes Over Time, Financial Analysts Journal 62, 89-100.

Bloom, N., M. Floetotto, N. Jaimovich, I. Sapora-Eksten, and S. Terry, 2012, Really uncertain business cycles, NBER working paper.

Bloom, N., S. Bond, and J. van Reenen, 2007, Uncertainty and Investment Dynamics, Review of Economic Studies 74, 391-415.

Brandt, M., A. Brav, J. Graham, and A. Kumar, 2010, The idiosyncratic volatility puzzle: Time trend or speculative episodes? Review of Financial Studies 23, 863-899.

Brown, G., and N. Kapadia, 2007, Firm-specific risk and equity market development, Journal of Financial Economics 84, 358-388.

Campbell, J., M. Lettau, B. Malkiel, and Y. Xu, 2001, Have individual stocks become more volatile? An empirical exploration of idiosyncratic risk, Journal of Finance 56, 1-43.

Cao, C., T. Simin, and J. Zhao, 2008, Can growth options explain the trend in idiosyncratic risk? Review of Financial Studies 21, 2599-2633.

Chun, H., J.-W. Kim, R. Morck, and B. Yeung, 2008, Creative destruction and firm-specific performance heterogeneity, Journal of Financial Economics 89, 109-135.

Comin, D., and S. Mulani, 2009, A theory of growth and volatility at the aggregate and firm level, Journal of Monetary Economics 56, 1023-1042.

Comin, D., and T. Philippon, 2005, The rise in firm-level volatility: Causes and consequences, NBER macroeconomics annual 20, 167-201.

Council of Economic Advisors, 2016, Benefits of competition and indicators of market power. 
Dechow, P.M., R.G. Sloan and M.T. Soliman, 2004, Implied equity duration: A new measure of equity risk, Review of Accounting Studies 9, 197-228.

Doidge, C., A. Karolyi, and R. Stulz, 2016, The U.S. listing gap, Journal of Financial Economics 123, 546573.

Fama, E. F., K. R. French, 2015, A five-factor asset pricing model, Journal of Financial Economics 116, $1-22$.

Fox, E.G., M.B. Fox, and R.J. Gilson, 2016, Economic crisis and the integration of law and finance: The impact of volatility spikes, Columbia Law Review 116, 325-408.

Gaspar, J.-M., and M. Massa, 2006, Idiosyncratic Volatility and Product Market Competition, Journal of Business 79, 3125-3152.

Gilchrist, S., J. Sim, and E. Zakrajsek, 2014, Uncertainty, financial frictions, and investment dynamics, Federal Reserve Board, FEDS working paper.

Grullon, G., Y. Larkin, and R. Michaely, 2016, Are U.S. industries becoming more concentrated? unpublished working paper.

Guiso, L., and G. Parigi, 1999, Investment and demand uncertainty, Quarterly Journal of Economics 114, $185-227$.

Irvine, P., and J. Pontiff, 2009, Idiosyncratic return volatility, cash flows, and product market competition, Review of Financial Studies 22, 1149-1177.

Kahle, K., and R.M. Stulz, 2017, Is the US public corporation in trouble? Journal of Economic Perspectives 31, 67-88.

Kellogg, R., 2014, The effect of uncertainty on investment: Evidence from Texas oil drilling, American Economic Review 104, 1698-1734.

Leahy, J., and T. Whited, 1996, The effect of uncertainty on investment: Some stylized facts, Journal of Money, Credit and Banking 28, 64-83.

Malkiel, B., and Y. Xu, 2003, Investigating the behavior of idiosyncratic volatility, Journal of Business 76, 613-644.

Orlik, A., N. Kozeniauskas, and L. Veldkamp, 2014, Black swans and the many shades of uncertainty, New York University, working paper.

Pástor, L., and P. Veronesi, 2003, Stock valuation and learning about profitability, Journal of Finance 58, 1749-1789.

Schwert, G.W., 1989, Why does stock market volatility change over time? Journal of Finance 44, 11151153.

Spiegel, M., and X. Wang, 2005, Cross-sectional variation in stock returns: Liquidity and idiosyncratic risk, Yale University, working paper.

Stein, L.C.D., and E. Stone, 2012, The effect of uncertainty on investment, hiring, and R\&D: Causal evidence from equity options, Stanford University, working paper.

Wei, S., and C. Zhang, 2006, Why did individual stocks become more volatile? Journal of Business 79, 259-292. 
Figure 1: Idiosyncratic Risk over Time

The figure plots average annualized measures of monthly idiosyncratic risk alternatively from the market model, the CLMX model, and the Fama French 5-factor model. Panel A shows equally-weighted averages, while Panel B shows value-weighted averages. Appendix A provides definitions of all variables.

\section{Panel A: Equally-weighted Idiosyncratic Risk}

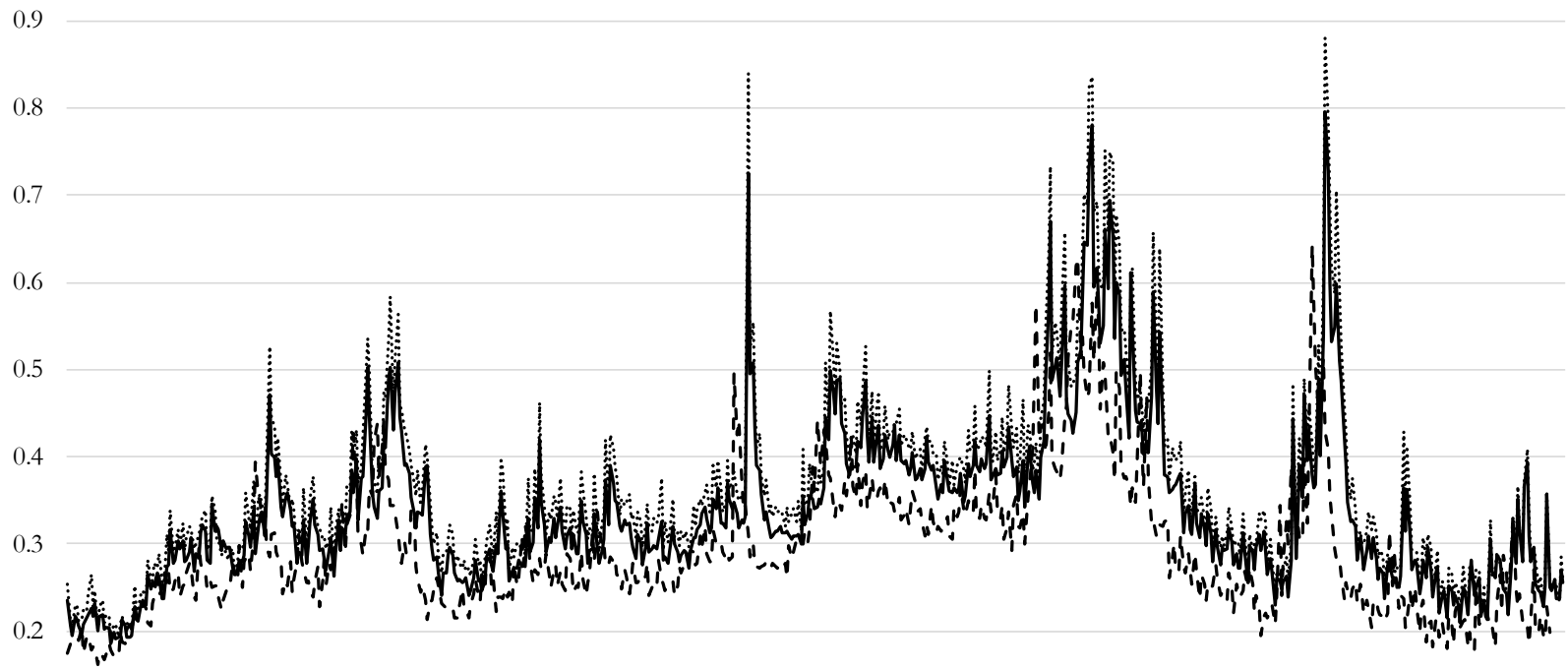

0.1

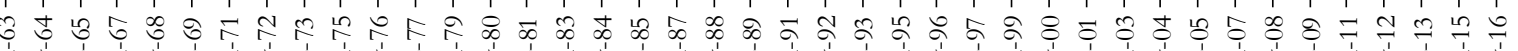

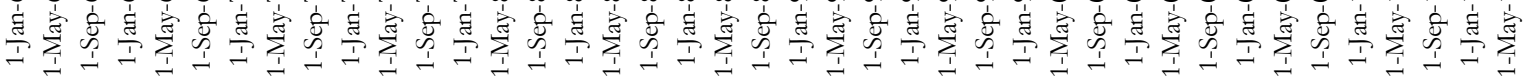

— Market Model …....... CLMX Model _ - - Fama-French 5-Factor Model

\section{Panel B: Value-weighted Idiosyncratic Risk}

0.7

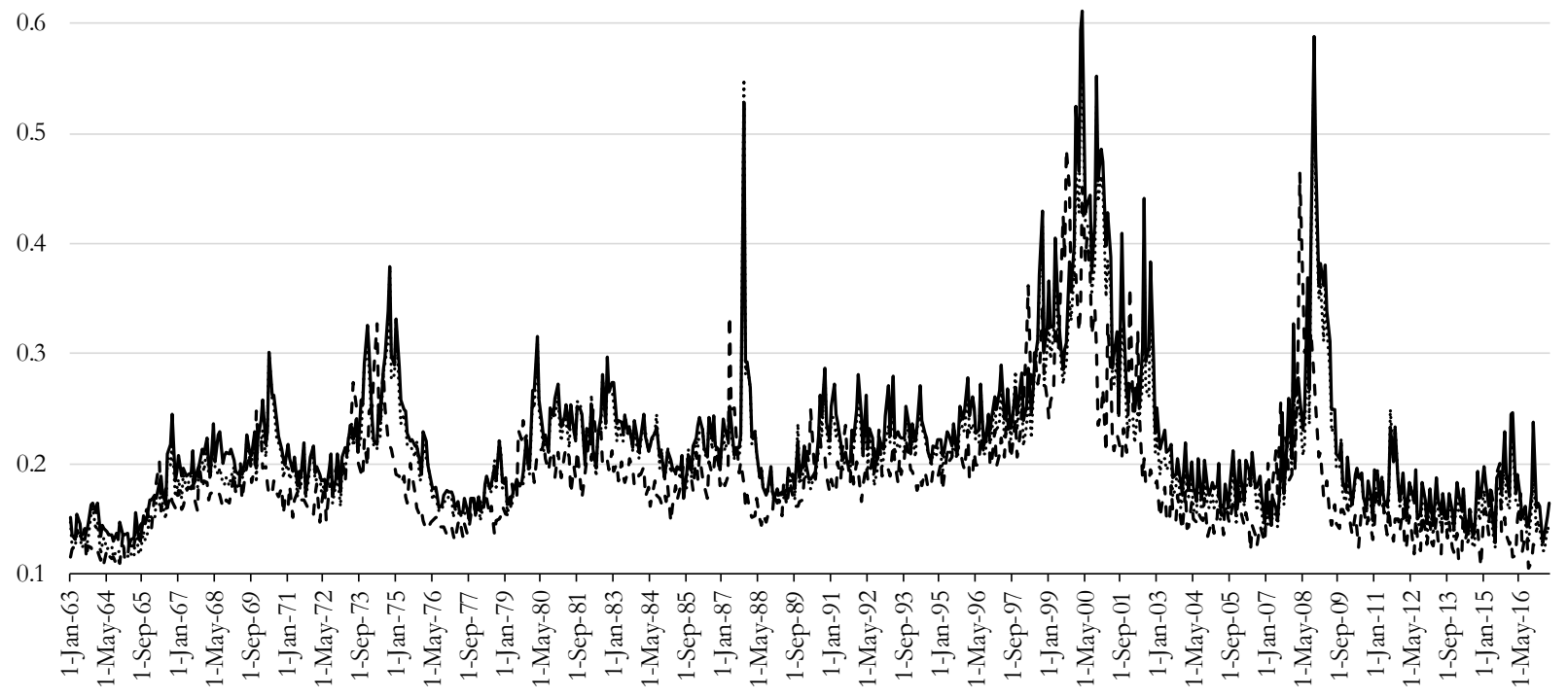

— Market Model …...... CLMX Model - - - Fama-French 5-Factor Model 


\section{Figure 2: Idiosyncratic Risk and Market Risk over Time}

The figure plots equally-weighted average annualized monthly idiosyncratic risk (left axis) and market risk (right axis) from the market model. Appendix A provides definitions of all variables.

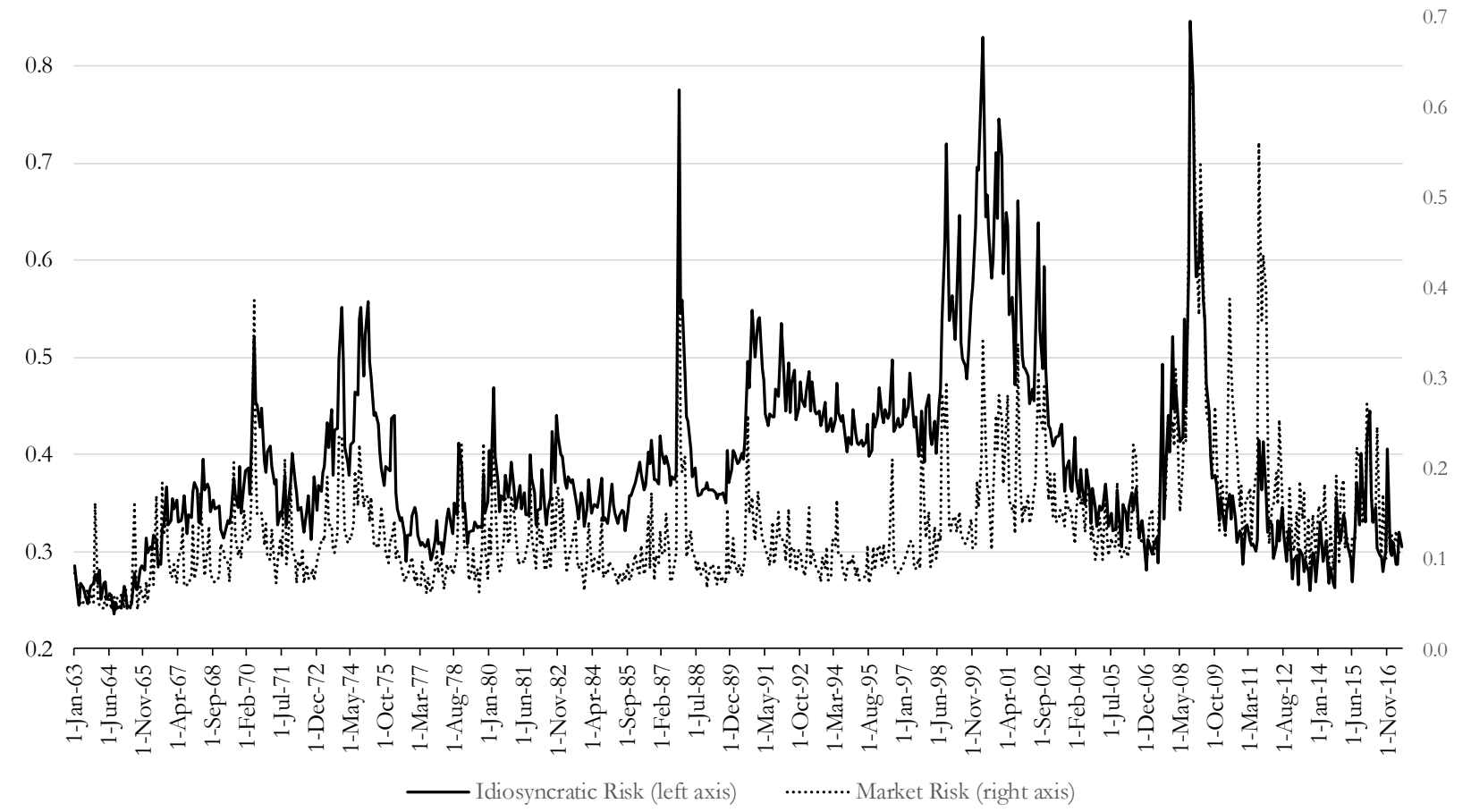




\section{Table 1: Regressions of Idiosyncratic Risk on 5-year Period Dummies}

The table shows results from regressions of average monthly annualized idiosyncratic risk on an intercept and indicator variables for non-overlapping 5-year periods. Idiosyncratic risk is alternatively from the market model, the CLMX model, and the Fama-French 5-factor model, and it is averaged each month either using equal-weighting or valueweighting. The table shows the regression coefficients and associated $p$-values, as well as the regression R-squared and the number of time-series observations. Panel A shows results for firms from all exchanges, while Panel B shows results for NYSE firms only, and Panel C shows results for Nasdaq firms only. $p$-values reported as [0.00] are significant at better than the $1 \%$ level. The sample period is 1/1963-6/2017. Appendix A provides definitions of all variables.

\begin{tabular}{|c|c|c|c|c|c|c|c|c|c|c|c|c|}
\hline \multirow[b]{4}{*}{ Panel A: All Exchang } & \multicolumn{6}{|c|}{ Equally-weighted Idiosyncratic Risk } & \multicolumn{6}{|c|}{ Value-weighted Idiosyncratic Risk } \\
\hline & \multicolumn{2}{|c|}{ Market Model } & \multicolumn{2}{|c|}{ CLMX Model } & \multicolumn{2}{|c|}{$\begin{array}{c}\text { Fama-French 5- } \\
\text { Factor Model }\end{array}$} & \multicolumn{2}{|c|}{ Market Model } & \multicolumn{2}{|c|}{ CLMX Model } & \multicolumn{2}{|c|}{$\begin{array}{c}\text { Fama-French } 5 \\
\text { Factor Model }\end{array}$} \\
\hline & Coef & $p$-value & Coef & $p$-value & Coef & $p$-value & Coef & $\overline{p \text {-value }}$ & Coef & $p$-value & Coef & $p$-value \\
\hline & & & & & & & & & & & & \\
\hline Intercept & 0.263 & {$[0.00]$} & 0.272 & {$[0.00]$} & 0.218 & {$[0.00]$} & 0.169 & {$[0.00]$} & 0.155 & {$[0.00]$} & 0.139 & {$[0.00]$} \\
\hline Years 2008-2012 & 0.088 & {$[0.00]$} & 0.109 & {$[0.00]$} & 0.077 & {$[0.00]$} & 0.061 & {$[0.00]$} & 0.061 & {$[0.00]$} & 0.049 & {$[0.00]$} \\
\hline Years 2003-2007 & 0.045 & {$[0.00]$} & 0.056 & {$[0.00]$} & 0.046 & {$[0.00]$} & 0.020 & {$[0.03]$} & 0.020 & {$[0.02]$} & 0.020 & {$[0.01]$} \\
\hline Years 1998-2002 & 0.250 & {$[0.00]$} & 0.289 & {$[0.00]$} & 0.222 & {$[0.00]$} & 0.184 & {$[0.00]$} & 0.171 & {$[0.00]$} & 0.154 & {$[0.00]$} \\
\hline Years 1993-1997 & 0.123 & {$[0.00]$} & 0.141 & {$[0.00]$} & 0.119 & {$[0.00]$} & 0.069 & {$[0.00]$} & 0.071 & {$[0.00]$} & 0.064 & {$[0.00]$} \\
\hline Years 1988-1992 & 0.116 & {$[0.00]$} & 0.134 & {$[0.00]$} & 0.114 & {$[0.00]$} & 0.043 & {$[0.00]$} & 0.050 & {$[0.00]$} & 0.044 & {$[0.00]$} \\
\hline Years 1983-1987 & 0.064 & {$[0.00]$} & 0.082 & {$[0.00]$} & 0.065 & {$[0.00]$} & 0.059 & {$[0.00]$} & 0.068 & {$[0.00]$} & 0.054 & {$[0.00]$} \\
\hline Years 1978-1982 & 0.044 & {$[0.00]$} & 0.060 & {$[0.00]$} & 0.047 & {$[0.00]$} & 0.053 & {$[0.00]$} & 0.062 & {$[0.00]$} & 0.048 & {$[0.00]$} \\
\hline Years 1973-1977 & 0.082 & {$[0.00]$} & 0.102 & {$[0.00]$} & 0.083 & {$[0.00]$} & 0.052 & {$[0.00]$} & 0.058 & {$[0.00]$} & 0.052 & {$[0.00]$} \\
\hline Years 1968-1972 & 0.053 & {$[0.00]$} & 0.060 & {$[0.00]$} & 0.056 & {$[0.00]$} & 0.040 & {$[0.00]$} & 0.043 & {$[0.00]$} & 0.039 & {$[0.00]$} \\
\hline Years 1963-1967 & -0.024 & {$[0.05]$} & -0.019 & {$[0.16]$} & -0.006 & {$[0.55]$} & -0.006 & {$[0.51]$} & -0.005 & {$[0.54]$} & 0.002 & {$[0.75]$} \\
\hline $\mathrm{R}^{2}$ & 0.54 & & 0.53 & & 0.57 & & 0.49 & & 0.48 & & 0.51 & \\
\hline Observations & 654 & & 654 & & 648 & & 654 & & 654 & & 648 & \\
\hline \multicolumn{13}{|l|}{ Panel B: NYSE } \\
\hline Intercept & 0.238 & {$[0.00]$} & 0.242 & {$[0.00]$} & 0.198 & {$[0.00]$} & 0.155 & {$[0.00]$} & 0.142 & {$[0.00]$} & 0.127 & {$[0.00]$} \\
\hline Years 2008-2012 & 0.082 & {$[0.00]$} & 0.100 & {$[0.00]$} & 0.070 & {$[0.00]$} & 0.064 & {$[0.00]$} & 0.061 & {$[0.00]$} & 0.050 & {$[0.00]$} \\
\hline Years 2003-2007 & 0.016 & {$[0.15]$} & 0.023 & {$[0.06]$} & 0.018 & {$[0.04]$} & 0.018 & {$[0.04]$} & 0.014 & {$[0.09]$} & 0.018 & {$[0.01]$} \\
\hline Years 1998-2002 & 0.151 & {$[0.00]$} & 0.183 & {$[0.00]$} & 0.135 & {$[0.00]$} & 0.158 & {$[0.00]$} & 0.138 & {$[0.00]$} & 0.134 & {$[0.00]$} \\
\hline Years 1993-1997 & 0.043 & {$[0.00]$} & 0.060 & {$[0.00]$} & 0.046 & {$[0.00]$} & 0.057 & {$[0.00]$} & 0.055 & {$[0.00]$} & 0.053 & {$[0.00]$} \\
\hline Years 1988-1992 & 0.066 & {$[0.00]$} & 0.085 & {$[0.00]$} & 0.067 & {$[0.00]$} & 0.041 & {$[0.00]$} & 0.044 & {$[0.00]$} & 0.041 & {$[0.00]$} \\
\hline Years 1983-1987 & 0.059 & {$[0.00]$} & 0.075 & {$[0.00]$} & 0.058 & {$[0.00]$} & 0.063 & {$[0.00]$} & 0.068 & {$[0.00]$} & 0.056 & {$[0.00]$} \\
\hline Years 1978-1982 & 0.071 & {$[0.00]$} & 0.088 & {$[0.00]$} & 0.070 & {$[0.00]$} & 0.064 & {$[0.00]$} & 0.069 & {$[0.00]$} & 0.057 & {$[0.00]$} \\
\hline Years 1973-1977 & 0.118 & {$[0.00]$} & 0.139 & {$[0.00]$} & 0.113 & {$[0.00]$} & 0.062 & {$[0.00]$} & 0.065 & {$[0.00]$} & 0.059 & {$[0.00]$} \\
\hline Years 1968-1972 & 0.077 & {$[0.00]$} & 0.090 & {$[0.00]$} & 0.075 & {$[0.00]$} & 0.054 & {$[0.00]$} & 0.056 & {$[0.00]$} & 0.050 & {$[0.00]$} \\
\hline Years 1963-1967 & 0.001 & {$[0.94]$} & 0.010 & {$[0.40]$} & 0.014 & [0.13] & 0.008 & {$[0.39]$} & 0.008 & {$[0.32]$} & 0.013 & {$[0.05]$} \\
\hline $\mathrm{R}^{2}$ & 0.37 & & 0.39 & & 0.40 & & 0.43 & & 0.42 & & 0.46 & \\
\hline Observations & 654 & & 654 & & 648 & & 654 & & 654 & & 648 & \\
\hline \multicolumn{13}{|l|}{ Panel C: Nasdaq } \\
\hline Intercept & 0.290 & {$[0.00]$} & 0.306 & {$[0.00]$} & 0.240 & {$[0.00]$} & 0.202 & {$[0.00]$} & 0.189 & {$[0.00]$} & 0.166 & {$[0.00]$} \\
\hline Years 2008-2012 & 0.092 & {$[0.00]$} & 0.114 & {$[0.00]$} & 0.081 & {$[0.00]$} & 0.060 & {$[0.00]$} & 0.073 & {$[0.00]$} & 0.053 & {$[0.00]$} \\
\hline Years 2003-2007 & 0.063 & {$[0.00]$} & 0.076 & {$[0.00]$} & 0.063 & {$[0.00]$} & 0.048 & {$[0.00]$} & 0.063 & {$[0.00]$} & 0.043 & {$[0.00]$} \\
\hline Years 1998-2002 & 0.319 & {$[0.00]$} & 0.361 & {$[0.00]$} & 0.284 & {$[0.00]$} & 0.281 & {$[0.00]$} & 0.289 & {$[0.00]$} & 0.230 & {$[0.00]$} \\
\hline Years 1993-1997 & 0.188 & {$[0.00]$} & 0.205 & {$[0.00]$} & 0.179 & {$[0.00]$} & 0.177 & {$[0.00]$} & 0.201 & {$[0.00]$} & 0.158 & {$[0.00]$} \\
\hline Years 1988-1992 & 0.172 & {$[0.00]$} & 0.189 & {$[0.00]$} & 0.167 & {$[0.00]$} & 0.138 & {$[0.00]$} & 0.172 & {$[0.00]$} & 0.130 & {$[0.00]$} \\
\hline Years 1983-1987 & 0.077 & {$[0.00]$} & 0.097 & {$[0.00]$} & 0.078 & {$[0.00]$} & 0.104 & {$[0.00]$} & 0.145 & {$[0.00]$} & 0.097 & {$[0.00]$} \\
\hline Years 1978-1982 & 0.010 & {$[0.51]$} & 0.032 & {$[0.08]$} & 0.017 & {$[0.19]$} & 0.051 & {$[0.00]$} & 0.094 & {$[0.00]$} & 0.050 & {$[0.00]$} \\
\hline Years 1973-1977 & 0.037 & [0.02] & 0.065 & {$[0.00]$} & 0.047 & {$[0.00]$} & 0.074 & {$[0.00]$} & 0.115 & {$[0.00]$} & 0.075 & {$[0.00]$} \\
\hline $\mathrm{R}^{2}$ & 0.59 & & 0.55 & & 0.62 & & 0.55 & & 0.51 & & 0.55 & \\
\hline Observations & 534 & & 534 & & 534 & & 534 & & 534 & & 534 & \\
\hline
\end{tabular}




\section{Table 2: Idiosyncratic Risk and Macroeconomic Variables}

The table reports the number of time-series observations $(\mathrm{N})$, means and medians of average risk levels of monthly time-series estimates of risk from the market model, the CLMX model, and the Fama-French 5-factor model, respectively. It also reports differences in means and medians and $p$-values for differences in sample means and medians based on non-parametric Wilcoxon tests. The table shows results by market and economic conditions based on various factors such as market risk, NBER recessions, the Chicago Fed National Activity Index, the level of the credit spread, the VIX index, the Uncertainty Index, and the Economic Policy Uncertainty Index. $p$-values reported as [0.00] are significant at better than the $1 \%$ level. The sample period is 1/1963-6/2017. Appendix A provides definitions of all variables.

\begin{tabular}{|c|c|c|c|c|c|c|c|c|c|c|}
\hline & \multicolumn{3}{|c|}{ High } & \multicolumn{3}{|c|}{ Low } & \multicolumn{4}{|c|}{ Difference } \\
\hline & $\mathrm{N}$ & Mean & Median & $\mathrm{N}$ & Mean & $\overline{\text { Median }}$ & Mean & $p$-value & Median & D-value \\
\hline \multicolumn{11}{|l|}{ CRSP Index Volatility } \\
\hline Total Risk & 327 & 0.437 & 0.403 & 327 & 0.321 & 0.314 & 0.116 & {$[0.00]$} & 0.089 & {$[0.00]$} \\
\hline Market Risk (CLMX Model) & 327 & 0.179 & 0.156 & 327 & 0.085 & 0.089 & 0.095 & {$[0.00]$} & 0.067 & {$[0.00]$} \\
\hline Market Risk (Market Model) & 327 & 0.177 & 0.155 & 327 & 0.093 & 0.093 & 0.084 & {$[0.00]$} & 0.063 & {$[0.00]$} \\
\hline Market Risk (CLMX Model 5-Day Returns) & 327 & 0.183 & 0.166 & 327 & 0.095 & 0.093 & 0.088 & {$[0.00]$} & 0.073 & {$[0.00]$} \\
\hline Idiosyncratic Risk (CLMX Model) & 327 & 0.412 & 0.384 & 327 & 0.318 & 0.308 & 0.094 & {$[0.00]$} & 0.077 & {$[0.00]$} \\
\hline Idiosyncratic Risk (Market Model) & 327 & 0.380 & 0.354 & 327 & 0.300 & 0.292 & 0.080 & {$[0.00]$} & 0.061 & {$[0.00]$} \\
\hline Idiosyncratic Risk (CLMX Model 5-Day Returns) & 327 & 0.383 & 0.360 & 327 & 0.296 & 0.293 & 0.086 & {$[0.00]$} & 0.067 & {$[0.00]$} \\
\hline Idiosyncratic Risk (Fama French 5-Factor Model) & 324 & 0.325 & 0.304 & 324 & 0.262 & 0.254 & 0.063 & {$[0.00]$} & 0.050 & {$[0.00]$} \\
\hline \multicolumn{11}{|l|}{ NBER Recessions } \\
\hline Total Risk & 83 & 0.488 & 0.464 & 571 & 0.364 & 0.341 & 0.125 & {$[0.00]$} & 0.123 & {$[0.00]$} \\
\hline Market Risk (CLMX Model) & 83 & 0.199 & 0.181 & 571 & 0.122 & 0.108 & 0.076 & {$[0.00]$} & 0.073 & {$[0.00]$} \\
\hline Market Risk (Market Model) & 83 & 0.201 & 0.160 & 571 & 0.125 & 0.109 & 0.075 & {$[0.00]$} & 0.050 & {$[0.00]$} \\
\hline Market Risk (CLMX Model 5-Day Returns) & 83 & 0.214 & 0.189 & 571 & 0.128 & 0.116 & 0.086 & {$[0.00]$} & 0.073 & {$[0.00]$} \\
\hline Idiosyncratic Risk (CLMX Model) & 83 & 0.457 & 0.446 & 571 & 0.352 & 0.335 & 0.105 & {$[0.00]$} & 0.111 & {$[0.00]$} \\
\hline Idiosyncratic Risk (Market Model) & 83 & 0.420 & 0.411 & 571 & 0.328 & 0.311 & 0.092 & {$[0.00]$} & 0.100 & {$[0.00]$} \\
\hline Idiosyncratic Risk (CLMX Model 5-Day Returns) & 83 & 0.424 & 0.411 & 571 & 0.327 & 0.312 & 0.097 & {$[0.00]$} & 0.099 & {$[0.00]$} \\
\hline Idiosyncratic Risk (Fama French 5-Factor Model) & 83 & 0.358 & 0.353 & 565 & 0.284 & 0.270 & 0.074 & {$[0.00]$} & 0.083 & {$[0.00]$} \\
\hline \multicolumn{11}{|l|}{ Chicago Fed National Activity Index } \\
\hline Total Risk & 327 & 0.353 & 0.338 & 327 & 0.406 & 0.370 & -0.053 & {$[0.00]$} & -0.032 & {$[0.00]$} \\
\hline Market Risk (CLMX Model) & 327 & 0.114 & 0.102 & 327 & 0.151 & 0.131 & -0.037 & {$[0.00]$} & -0.029 & {$[0.00]$} \\
\hline Market Risk (Market Model) & 327 & 0.115 & 0.102 & 327 & 0.155 & 0.131 & -0.039 & {$[0.00]$} & -0.029 & {$[0.00]$} \\
\hline Market Risk (CLMX Model 5-Day Returns) & 327 & 0.124 & 0.114 & 327 & 0.154 & 0.133 & -0.030 & {$[0.00]$} & -0.019 & {$[0.00]$} \\
\hline Idiosyncratic Risk (CLMX Model) & 327 & 0.345 & 0.331 & 327 & 0.386 & 0.358 & -0.042 & {$[0.00]$} & -0.028 & {$[0.00]$} \\
\hline Idiosyncratic Risk (Market Model) & 327 & 0.322 & 0.310 & 327 & 0.358 & 0.329 & -0.036 & {$[0.00]$} & -0.018 & {$[0.00]$} \\
\hline Idiosyncratic Risk (CLMX Model 5-Day Returns) & 327 & 0.319 & 0.311 & 327 & 0.360 & 0.337 & -0.040 & {$[0.00]$} & -0.026 & {$[0.00]$} \\
\hline Idiosyncratic Risk (Fama French 5-Factor Model) & 324 & 0.280 & 0.270 & 324 & 0.307 & 0.286 & -0.027 & {$[0.00]$} & -0.016 & {$[0.00]$} \\
\hline \multicolumn{11}{|l|}{ Credit Spread } \\
\hline Total Risk & 326 & 0.415 & 0.372 & 328 & 0.344 & 0.331 & 0.070 & {$[0.00]$} & 0.041 & {$[0.00]$} \\
\hline Market Risk (CLMX Model) & 326 & 0.157 & 0.138 & 328 & 0.107 & 0.099 & 0.049 & {$[0.00]$} & 0.039 & {$[0.00]$} \\
\hline Market Risk (Market Model) & 326 & 0.162 & 0.141 & 328 & 0.108 & 0.099 & 0.055 & {$[0.00]$} & 0.042 & {$[0.00]$} \\
\hline Market Risk (CLMX Model 5-Day Returns) & 326 & 0.159 & 0.140 & 328 & 0.120 & 0.110 & 0.039 & {$[0.00]$} & 0.030 & {$[0.00]$} \\
\hline Idiosyncratic Risk (CLMX Model) & 326 & 0.391 & 0.353 & 328 & 0.340 & 0.329 & 0.051 & {$[0.00]$} & 0.024 & {$[0.00]$} \\
\hline Idiosyncratic Risk (Market Model) & 326 & 0.362 & 0.328 & 328 & 0.317 & 0.308 & 0.045 & {$[0.00]$} & 0.019 & {$[0.00]$} \\
\hline Idiosyncratic Risk (CLMX Model 5-Day Returns) & 326 & 0.366 & 0.336 & 328 & 0.313 & 0.309 & 0.053 & {$[0.00]$} & 0.027 & {$[0.00]$} \\
\hline Idiosyncratic Risk (Fama French 5-Factor Model) & 323 & 0.310 & 0.284 & 325 & 0.278 & 0.270 & 0.032 & {$[0.00]$} & 0.014 & {$[0.00]$} \\
\hline
\end{tabular}

(continued) 
Table 2: Idiosyncratic Volatility and Macroeconomic Variables (continued)

\begin{tabular}{|c|c|c|c|c|c|c|c|c|c|c|}
\hline \multirow[b]{2}{*}{ Risk Measure } & \multicolumn{3}{|c|}{ High } & \multicolumn{3}{|c|}{ Low } & \multicolumn{4}{|c|}{ Difference } \\
\hline & $\mathrm{N}$ & Mean & $\overline{\text { Median }}$ & $\mathrm{N}$ & Mean & $\overline{\text { Median }}$ & Mean & $p$-value & Median & $\overline{p \text {-value }}$ \\
\hline \multicolumn{11}{|l|}{ VIX Index } \\
\hline Total Risk & 184 & 0.489 & 0.451 & 189 & 0.347 & 0.338 & 0.142 & {$[0.00]$} & 0.114 & {$[0.00]$} \\
\hline Market Risk (CLMX Model) & 184 & 0.195 & 0.170 & 189 & 0.103 & 0.098 & 0.092 & {$[0.00]$} & 0.072 & {$[0.00]$} \\
\hline Market Risk (Market Model) & 184 & 0.191 & 0.157 & 189 & 0.122 & 0.113 & 0.069 & {$[0.00]$} & 0.044 & {$[0.00]$} \\
\hline Market Risk (CLMX Model 5-Day Returns) & 184 & 0.190 & 0.169 & 189 & 0.101 & 0.098 & 0.090 & {$[0.00]$} & 0.071 & {$[0.00]$} \\
\hline Idiosyncratic Risk (CLMX Model) & 184 & 0.463 & 0.429 & 189 & 0.332 & 0.324 & 0.131 & {$[0.00]$} & 0.105 & {$[0.00]$} \\
\hline Idiosyncratic Risk (Market Model) & 184 & 0.425 & 0.395 & 189 & 0.313 & 0.305 & 0.112 & {$[0.00]$} & 0.091 & {$[0.00]$} \\
\hline Idiosyncratic Risk (CLMX Model 5-Day Returns) & 184 & 0.424 & 0.396 & 189 & 0.305 & 0.301 & 0.119 & {$[0.00]$} & 0.096 & {$[0.00]$} \\
\hline Idiosyncratic Risk (Fama French 5-Factor Model) & 184 & 0.363 & 0.342 & 189 & 0.269 & 0.259 & 0.094 & {$[0.00]$} & 0.084 & {$[0.00]$} \\
\hline \multicolumn{11}{|l|}{ Uncertainty Index } \\
\hline Total Risk & 258 & 0.427 & 0.394 & 261 & 0.379 & 0.358 & 0.047 & {$[0.00]$} & 0.036 & {$[0.00]$} \\
\hline Market Risk (CLMX Model) & 258 & 0.154 & 0.130 & 261 & 0.128 & 0.112 & 0.026 & {$[0.00]$} & 0.018 & {$[0.00]$} \\
\hline Market Risk (Market Model) & 258 & 0.155 & 0.123 & 261 & 0.127 & 0.111 & 0.028 & {$[0.00]$} & 0.011 & {$[0.00]$} \\
\hline Market Risk (CLMX Model 5-Day Returns) & 258 & 0.158 & 0.140 & 261 & 0.139 & 0.126 & 0.019 & {$[0.00]$} & 0.014 & {$[0.04]$} \\
\hline Idiosyncratic Risk (CLMX Model) & 258 & 0.410 & 0.385 & 261 & 0.372 & 0.347 & 0.039 & {$[0.00]$} & 0.038 & {$[0.00]$} \\
\hline Idiosyncratic Risk (Market Model) & 258 & 0.379 & 0.359 & 261 & 0.345 & 0.323 & 0.034 & {$[0.00]$} & 0.036 & {$[0.00]$} \\
\hline Idiosyncratic Risk (CLMX Model 5-Day Returns) & 258 & 0.378 & 0.356 & 261 & 0.345 & 0.326 & 0.033 & {$[0.00]$} & 0.030 & {$[0.00]$} \\
\hline Idiosyncratic Risk (Fama French 5-Factor Model) & 258 & 0.326 & 0.311 & 261 & 0.299 & 0.280 & 0.027 & {$[0.00]$} & 0.031 & {$[0.00]$} \\
\hline \multicolumn{11}{|l|}{ Economic Policy Uncertainty Index } \\
\hline Total Risk & 195 & 0.430 & 0.393 & 195 & 0.396 & 0.378 & 0.034 & {$[0.01]$} & 0.014 & {$[0.11]$} \\
\hline Market Risk (CLMX Model) & 195 & 0.166 & 0.143 & 195 & 0.126 & 0.111 & 0.040 & {$[0.00]$} & 0.032 & {$[0.00]$} \\
\hline Market Risk (Market Model) & 195 & 0.179 & 0.148 & 195 & 0.127 & 0.117 & 0.052 & {$[0.00]$} & 0.031 & {$[0.00]$} \\
\hline Market Risk (CLMX Model 5-Day Returns) & 195 & 0.164 & 0.140 & 195 & 0.123 & 0.115 & 0.041 & {$[0.00]$} & 0.025 & {$[0.00]$} \\
\hline Idiosyncratic Risk (CLMX Model) & 195 & 0.397 & 0.367 & 195 & 0.390 & 0.382 & 0.007 & {$[0.57]$} & -0.014 & {$[0.95]$} \\
\hline Idiosyncratic Risk (Market Model) & 195 & 0.368 & 0.345 & 195 & 0.363 & 0.355 & 0.005 & {$[0.61]$} & -0.010 & {$[0.91]$} \\
\hline Idiosyncratic Risk (CLMX Model 5-Day Returns) & 195 & 0.365 & 0.344 & 195 & 0.357 & 0.335 & 0.008 & {$[0.44]$} & 0.009 & {$[0.63]$} \\
\hline Idiosyncratic Risk (Fama French 5-Factor Model) & 195 & 0.314 & 0.293 & 195 & 0.313 & 0.308 & 0.001 & {$[0.90]$} & -0.015 & {$[0.79]$} \\
\hline
\end{tabular}




\section{Table 3: Time-Series Regressions of Idiosyncratic Risk on Macroeconomic Variables}

The table presents results of time-series regressions with monthly measures of the natural logarithm of idiosyncratic risk as the dependent variable. Average risk variables are alternatively from the market model, the CLMX model or the Fama-French 5-factor model. Explanatory variables are market risk, the credit spread, NBER recessions, the Chicago Fed National Activity Index, and the return on the CRSP value-weighted index. Panel A shows results for timeseries regressions with contemporaneous regressors. Panel B shows results for time-series regressions with contemporaneous and lagged regressors. Panel $\mathrm{C}$ shows results for time-series regressions of changes (first differences) in idiosyncratic risk on levels and changes (first differences) in macroeconomic variables. The table reports the regression coefficients and associated $p$-values, as well as the adjusted R-squared and the number of observations. $p$-values reported as [0.00] are significant at better than the 1\% level. The sample period is 1/1963-6/2017. Appendix A provides definitions of all variables.

\section{Panel A: Time-Series Regressions with Contemporaneous Regressors}

\begin{tabular}{|c|c|c|c|c|c|c|c|c|c|c|c|c|}
\hline & \multicolumn{6}{|c|}{ Equally-weighted Idiosyncratic Risk } & \multicolumn{6}{|c|}{ Value-weighted Idiosyncratic Risk } \\
\hline & \multicolumn{2}{|c|}{ Market Model } & \multicolumn{2}{|c|}{ CLMX Model } & \multicolumn{2}{|c|}{$\begin{array}{l}\text { Fama-French 5- } \\
\text { Factor Model }\end{array}$} & \multicolumn{2}{|c|}{ Market Model } & \multicolumn{2}{|c|}{ CLMX Model } & \multicolumn{2}{|c|}{$\begin{array}{c}\text { Fama-French 5- } \\
\text { Factor Model }\end{array}$} \\
\hline & Coef & $p$-value & Coef & $p$-value & Coef & $p$-value & Coef & $p$-value & Coef & $p$-value & Coef & $p$-value \\
\hline Market Risk (log) & 0.145 & {$[0.00]$} & 0.386 & {$[0.00]$} & 0.109 & {$[0.00]$} & 0.301 & {$[0.00]$} & 0.406 & {$[0.00]$} & 0.284 & {$[0.00]$} \\
\hline Credit Spread & 0.034 & [0.02] & -0.018 & {$[0.16]$} & 0.029 & {$[0.06]$} & -0.010 & {$[0.45]$} & -0.022 & {$[0.09]$} & -0.018 & {$[0.20]$} \\
\hline NBER Recessions & 0.160 & {$[0.00]$} & 0.098 & {$[0.00]$} & 0.165 & {$[0.00]$} & 0.151 & {$[0.00]$} & 0.108 & {$[0.00]$} & 0.151 & {$[0.00]$} \\
\hline Chicago Fed Index & -0.004 & {$[0.73]$} & -0.003 & [0.79] & -0.005 & {$[0.66]$} & 0.002 & {$[0.86]$} & 0.003 & [0.82] & 0.002 & {$[0.87]$} \\
\hline CRSP VW-Return & 0.049 & [0.82] & 0.517 & {$[0.01]$} & 0.103 & {$[0.64]$} & 0.314 & [0.12] & 0.412 & {$[0.03]$} & 0.466 & {$[0.02]$} \\
\hline Intercept & -0.988 & {$[0.00]$} & -0.336 & {$[0.00]$} & -1.222 & {$[0.00]$} & -0.936 & {$[0.00]$} & -0.865 & {$[0.00]$} & -1.140 & {$[0.00]$} \\
\hline Adjusted $\mathrm{R}^{2}$ & 0.24 & & 0.47 & & 0.18 & & 0.38 & & 0.48 & & 0.34 & \\
\hline Observations & 654 & & 654 & & 648 & & 654 & & 654 & & 648 & \\
\hline
\end{tabular}

Panel B: Time-Series Regressions with Contemporaneous and Lagged Regressors

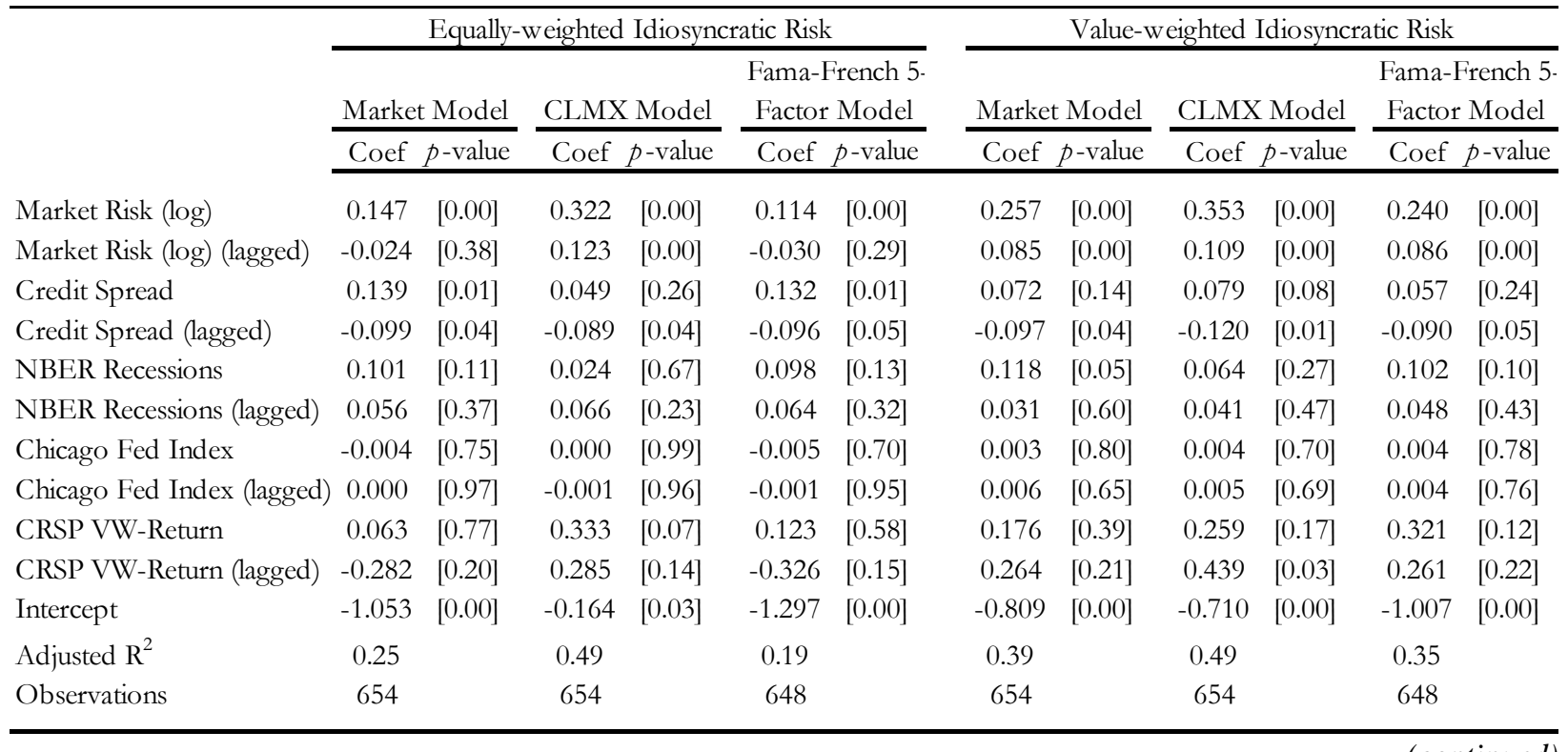


Table 3: Time-Series Regressions of Idiosyncratic Risk on Macroeconomic Variables (continued)

\section{Panel C: Time-Series Regressions with Changes}

\begin{tabular}{|c|c|c|c|c|c|c|c|c|c|c|c|}
\hline & \multicolumn{5}{|c|}{ Equally-weighted Idiosyncratic Risk } & \multicolumn{6}{|c|}{ Value-weighted Idiosyncratic Risk } \\
\hline & Marke & t Model & CLMX Model & $\begin{array}{r}\text { Fama-F } \\
\text { Factor } \\
\end{array}$ & $\begin{array}{l}\text { French 5- } \\
\text { r Model }\end{array}$ & Marke & t Model & CLMX & Model & $\begin{array}{r}\text { Fama-F } \\
\text { Factor }\end{array}$ & $\begin{array}{l}\text { rench 5- } \\
\text { Model }\end{array}$ \\
\hline & Coef & $p$-value & Coef $p$-value & Coef & $p$-value & Coef & $p$-value & Coef & $p$-value & Coef & $p$-value \\
\hline Market Risk (change) & 0.520 & {$[0.00]$} & $0.645[0.00]$ & 0.354 & {$[0.00]$} & 0.425 & {$[0.00]$} & 0.436 & {$[0.00]$} & 0.282 & {$[0.00]$} \\
\hline Credit Spread (change) & 0.047 & {$[0.00]$} & $0.057[0.00]$ & 0.045 & {$[0.00]$} & 0.026 & {$[0.00]$} & 0.029 & {$[0.00]$} & 0.025 & {$[0.00]$} \\
\hline NBER Recession & 0.008 & {$[0.16]$} & $0.005[0.46]$ & 0.005 & {$[0.24]$} & 0.002 & {$[0.66]$} & 0.002 & {$[0.71]$} & 0.001 & [0.83] \\
\hline Chicago Fed Index & 0.005 & {$[0.03]$} & $0.004[0.15]$ & 0.004 & {$[0.05]$} & 0.002 & {$[0.32]$} & 0.002 & {$[0.31]$} & 0.001 & [0.41] \\
\hline Chicago Fed Index (change) & -0.002 & {$[0.36]$} & $0.000[0.85]$ & -0.002 & {$[0.27]$} & -0.001 & {$[0.74]$} & 0.000 & [0.94] & -0.001 & [0.64] \\
\hline CRSP VW-Return & 0.082 & {$[0.01]$} & $0.089[0.02]$ & 0.079 & {$[0.00]$} & 0.067 & {$[0.01]$} & 0.062 & [0.02] & 0.059 & {$[0.01]$} \\
\hline Time & 0.005 & {$[0.45]$} & $0.005[0.58]$ & 0.004 & {$[0.54]$} & 0.003 & {$[0.64]$} & 0.003 & {$[0.65]$} & 0.001 & {$[0.79]$} \\
\hline Intercept & -0.006 & {$[0.08]$} & $-0.01[0.19]$ & -0.004 & [0.10] & -0.002 & {$[0.41]$} & -0.002 & {$[0.40]$} & -0.001 & [0.51] \\
\hline Adjusted $\mathrm{R}^{2}$ & 0.48 & & 0.44 & 0.40 & & 0.46 & & 0.42 & & 0.38 & \\
\hline Observations & 654 & & 654 & 647 & & 654 & & 654 & & 647 & \\
\hline
\end{tabular}




\section{Table 4: Forecast Errors in 2013-2017 from Regressions with Macroeconomic Variables}

The table presents results from time-series regressions with monthly measures of the natural logarithm of idiosyncratic risk as the dependent variable. Risk variables are from the market model. Explanatory variables are market risk, the credit spread, NBER recessions, the Chicago Fed National Activity Index, and the return on the CRSP value-weighted index. Idiosyncratic risk and market risk are alternatively equally-weighted or value-weighted as indicated in the table rows. The regression is estimated over the period 1963-2012. The estimated regression coefficients are then used to predict idiosyncratic risk for each month in the period 2013-2017. The table reports average and median actual and predicated average idiosyncratic risk over 2013-2017 as well as average and median forecast errors and associated $p$ values. $p$-values reported as [0.00] are significant at better than the $1 \%$ level. The sample period is 1/1963-6/2017. Appendix A provides definitions of all variables.

\begin{tabular}{|c|c|c|c|c|c|c|c|c|}
\hline & \multicolumn{2}{|c|}{ Actual Idiosyncratic Risk } & \multicolumn{2}{|c|}{ Predicted Idiosyncratic Risk } & \multicolumn{4}{|c|}{ Forecast Error } \\
\hline & Mean & Median & Mean & Median & Mean & $p$-value & Median & $p$-value \\
\hline Equal-w eighting & 0.2626 & 0.2513 & 0.3139 & 0.3101 & -0.0513 & {$[0.00]$} & -0.0570 & {$[0.00]$} \\
\hline Value-weighting & 0.1687 & 0.1664 & 0.1976 & 0.1960 & -0.0289 & {$[0.00]$} & -0.0301 & {$[0.00]$} \\
\hline
\end{tabular}


Table 5: Differences in Firm Characteristics between 1996-2000 and 2013-2017

The table reports differences in firm characteristics between 1996-2000 and 2013-2017. For each of the time periods, we calculate each month the cross-sectional mean and median and subsequently average across months. We also calculate the difference in the average mean and median and test whether means and medians are significantly different across the two time periods. $p$-values reported as [0.00] are significant at better than the $1 \%$ level. Appendix A provides definitions of all variables.

\begin{tabular}{|c|c|c|c|c|c|c|c|c|}
\hline & \multicolumn{2}{|c|}{$1996-2000$} & \multicolumn{2}{|c|}{$2013-2017$} & \multicolumn{4}{|c|}{ Difference } \\
\hline & Mean & Median & Mean & Median & Mean & $p$-value & Median & $p$-value \\
\hline Idiosyncratic Risk (Market Model) & 0.472 & 0.405 & 0.263 & 0.210 & -0.209 & {$[0.00]$} & -0.195 & {$[0.00]$} \\
\hline Idiosyncratic Risk (CLMX Model) & 0.516 & 0.450 & 0.272 & 0.221 & -0.243 & {$[0.00]$} & -0.229 & {$[0.00]$} \\
\hline Idiosyncratic Risk (Fama-French 5-Factor Model) & 0.408 & 0.377 & 0.218 & 0.211 & -0.191 & {$[0.00]$} & -0.166 & {$[0.00]$} \\
\hline Book/Market & 0.530 & 0.432 & 0.521 & 0.421 & -0.010 & {$[0.43]$} & -0.011 & {$[0.13]$} \\
\hline Leverage & 0.288 & 0.241 & 0.278 & 0.244 & -0.010 & {$[0.01]$} & 0.003 & {$[0.48]$} \\
\hline Illiquidity Ratio & 0.159 & 0.022 & 0.004 & 0.001 & -0.156 & {$[0.00]$} & -0.021 & {$[0.00]$} \\
\hline Capital Expenditures/Total Assets & 0.053 & 0.035 & 0.041 & 0.025 & -0.012 & {$[0.00]$} & -0.010 & {$[0.00]$} \\
\hline R\&D Expenses/Total Assets & 0.037 & 0.000 & 0.035 & 0.000 & -0.001 & {$[0.01]$} & 0.000 & {$[1.00]$} \\
\hline Cash and Short-term Investments/Total Assets & 0.159 & 0.056 & 0.178 & 0.092 & 0.019 & {$[0.00]$} & 0.036 & {$[0.00]$} \\
\hline Firm Age & 14.25 & 8.307 & 22.62 & 18.26 & 8.374 & {$[0.00]$} & 9.952 & {$[0.00]$} \\
\hline Real Market Capitalization & 2,642 & 347 & 6,240 & 1,236 & 3,598 & {$[0.00]$} & 889 & {$[0.00]$} \\
\hline $\mathrm{ROE}$ & 0.040 & 0.108 & 0.060 & 0.094 & 0.020 & {$[0.00]$} & -0.014 & {$[0.00]$} \\
\hline Revenue Herfindahl Index & 0.086 & 0.044 & 0.117 & 0.081 & 0.032 & {$[0.00]$} & 0.038 & {$[0.00]$} \\
\hline S\&P Constituent & 0.090 & 0.000 & 0.191 & 0.000 & 0.101 & {$[0.00]$} & 0.000 & {$[1.00]$} \\
\hline Institutional Ownership & 0.425 & 0.42 & 0.615 & 0.647 & 0.191 & {$[0.00]$} & 0.227 & {$[0.00]$} \\
\hline
\end{tabular}




\section{Table 6: Regressions of Idiosyncratic Risk on Firm Characteristics}

The table presents results from regressions with monthly measures of the natural logarithm of idiosyncratic risk from the market model as dependent variable Result are shown alternatively for the full sample period (1963-2017) and the 1983-2017 subperiod. All regressions include as explanatory variables market-model market risk, the credit spread, NBER recessions, the Chicago Fed National Activity Index, and the return on the CRSP value-weighted index. The coefficients on these variables and the regression intercepts are not shown in Panel A, but the variables are included in all regressions. Panel A shows results from twelve firmlevel panel regressions, where the characteristics listed in the first column are added individually to the macroeconomic variables. The panel reports the coefficient and associated $p$-value on the listed characteristic, the adjusted regression R-squared and the number of observations. Standard errors are clustered by firm and month. Panel B shows results from firm-level panel regressions with multiple firm characteristics. Here, the coefficients and $p$-values of all regressors are reported, as well as the adjusted regression R-squared and the number of observations. Standard errors are clustered by firm and month. Panel C shows results from timeseries regressions with average firm characteristics. The panel reports the regression coefficients and associated $p$-values, the adjusted regression R-squared and the number of observations. $p$-values reported as [0.00] are significant at better than the 1\% level. The sample period is 1/1963-6/2017. Appendix A provides definitions of all variables.

\section{Panel A: Panel Regressions with Individual Firm Characteristics}

\begin{tabular}{|c|c|c|c|c|c|c|c|c|c|}
\hline & & \multicolumn{4}{|c|}{$1963-2017$} & \multicolumn{4}{|c|}{ 1983-2017 } \\
\hline & & \multicolumn{4}{|c|}{ Adjusted } & \multicolumn{4}{|c|}{ Adjusted } \\
\hline & & Coef & $p$-value & $\mathrm{R}^{2}$ & Observations & Coef & $p$-value & $\mathrm{R}^{2}$ & Observations \\
\hline$(1)$ & Illiquidity Ratio (log) (lagged) & 0.084 & {$[0.00]$} & 0.20 & $1,450,122$ & 0.093 & {$[0.00]$} & 0.22 & $1,221,055$ \\
\hline$(2)$ & Real Market Capitalization (log) (lagged) & -0.168 & {$[0.00]$} & 0.26 & $1,450,122$ & -0.170 & {$[0.00]$} & 0.26 & $1,221,055$ \\
\hline (3) & Firm Age (log) (lagged) & -0.230 & {$[0.00]$} & 0.20 & $1,450,122$ & -0.237 & {$[0.00]$} & 0.20 & $1,221,055$ \\
\hline$(4)$ & Book/Market (lagged) & -0.017 & {$[0.08]$} & 0.07 & $1,450,122$ & -0.019 & {$[0.09]$} & 0.07 & $1,221,055$ \\
\hline$(5)$ & Leverage (lagged) & -0.097 & {$[0.00]$} & 0.07 & $1,450,122$ & -0.147 & {$[0.00]$} & 0.08 & $1,221,055$ \\
\hline$(6)$ & Capital Expenditures/Total Assets (lagged) & 1.000 & {$[0.00]$} & 0.08 & $1,450,122$ & 0.998 & {$[0.00]$} & 0.08 & $1,221,055$ \\
\hline$(7)$ & R\&D/Total Assets (lagged) & 1.864 & {$[0.00]$} & 0.12 & $1,450,122$ & 1.818 & {$[0.00]$} & 0.12 & $1,221,055$ \\
\hline$(8)$ & Cash and Short-term Investments/Total Assets (log) (lagged) & 0.942 & {$[0.00]$} & 0.12 & $1,450,122$ & 0.958 & {$[0.00]$} & 0.13 & $1,221,055$ \\
\hline$(9)$ & ROE (lagged) & -0.700 & {$[0.00]$} & 0.15 & $1,450,122$ & -0.688 & {$[0.00]$} & 0.15 & $1,221,055$ \\
\hline$(10)$ & Revenue Herfindahl Index (log) (lagged) & 0.020 & {$[0.00]$} & 0.07 & $1,450,122$ & 0.015 & [0.03] & 0.07 & $1,221,055$ \\
\hline (11) & S\&P Constituent (lagged) & -0.419 & {$[0.00]$} & 0.12 & $1,448,528$ & -0.453 & {$[0.00]$} & 0.13 & $1,221,055$ \\
\hline (12) & Institutional Ownership (lagged) & -0.510 & {$[0.00]$} & 0.12 & $1,254,656$ & -0.544 & {$[0.00]$} & 0.13 & $1,208,531$ \\
\hline
\end{tabular}


Table 6: Regressions of Idiosyncratic Risk on Firm Characteristics (continued)

Panel B: Panel Regressions with Multiple Firm Characteristics

\begin{tabular}{|c|c|c|c|c|c|c|c|c|c|c|c|c|}
\hline & \multicolumn{6}{|c|}{$1963-2017$} & \multicolumn{6}{|c|}{$1983-2017$} \\
\hline & \multicolumn{2}{|c|}{ (1) } & \multicolumn{2}{|c|}{ (2) } & \multicolumn{2}{|c|}{ (3) } & \multicolumn{2}{|c|}{ (1) } & \multicolumn{2}{|c|}{ (2) } & \multicolumn{2}{|c|}{ (3) } \\
\hline & Coef & $\overline{p \text {-value }}$ & Coef & $p$-value & Coef & $\overline{p \text {-value }}$ & Coef & $\overline{p \text {-value }}$ & Coef & $\overline{p \text {-value }}$ & Coef & $p$-value \\
\hline Market Risk (Market Model) (log) (lagged) & 0.120 & {$[0.00]$} & & & 0.116 & {$[0.00]$} & 0.124 & {$[0.00]$} & & & 0.119 & {$[0.00]$} \\
\hline Credit Spread (lagged) & -0.021 & {$[0.11]$} & & & 0.013 & {$[0.21]$} & -0.077 & {$[0.00]$} & & & -0.010 & {$[0.44]$} \\
\hline NBER Recessions (lagged) & 0.149 & {$[0.00]$} & & & 0.110 & {$[0.00]$} & 0.242 & {$[0.00]$} & & & 0.147 & {$[0.00]$} \\
\hline Chicago Fed Index (lagged) & -0.021 & {$[0.12]$} & & & -0.018 & {$[0.09]$} & -0.035 & {$[0.09]$} & & & -0.030 & {$[0.07]$} \\
\hline CRSP VW-Return (lagged) & -0.555 & {$[0.03]$} & & & -0.541 & {$[0.01]$} & -0.702 & {$[0.03]$} & & & -0.672 & {$[0.01]$} \\
\hline Illiquidity Ratio (log) (lagged) & & & 0.010 & {$[0.01]$} & 0.022 & {$[0.00]$} & & & 0.020 & {$[0.00]$} & 0.036 & {$[0.00]$} \\
\hline Real Market Capitalization (log) (lagged) & & & -0.100 & {$[0.00]$} & -0.095 & {$[0.00]$} & & & -0.079 & {$[0.00]$} & -0.070 & {$[0.00]$} \\
\hline Firm Age (log) (lagged) & & & -0.118 & {$[0.00]$} & -0.111 & {$[0.00]$} & & & -0.128 & {$[0.00]$} & -0.122 & {$[0.00]$} \\
\hline Book/Market (lagged) & & & -0.012 & {$[0.17]$} & -0.040 & {$[0.00]$} & & & -0.019 & {$[0.09]$} & -0.042 & {$[0.00]$} \\
\hline Leverage (lagged) & & & 0.145 & {$[0.00]$} & 0.136 & {$[0.00]$} & & & 0.148 & {$[0.00]$} & 0.134 & {$[0.00]$} \\
\hline Capital Expenditures/Total Assets (lagged) & & & 1.152 & {$[0.00]$} & 1.101 & {$[0.00]$} & & & 1.284 & {$[0.00]$} & 1.165 & {$[0.00]$} \\
\hline R\&D/Total Assets (lagged) & & & 0.745 & {$[0.00]$} & 0.626 & {$[0.00]$} & & & 0.723 & {$[0.00]$} & 0.609 & {$[0.00]$} \\
\hline Cash and Short-term Investments/Total Assets (log) (lagged) & & & 0.523 & {$[0.00]$} & 0.436 & {$[0.00]$} & & & 0.562 & {$[0.00]$} & 0.464 & {$[0.00]$} \\
\hline ROE (lagged) & & & -0.342 & {$[0.00]$} & -0.309 & {$[0.00]$} & & & -0.338 & {$[0.00]$} & -0.296 & {$[0.00]$} \\
\hline Intercept & -0.872 & {$[0.00]$} & -0.394 & {$[0.00]$} & -0.109 & {$[0.00]$} & -0.726 & {$[0.00]$} & -0.461 & {$[0.00]$} & -0.122 & {$[0.00]$} \\
\hline Adjusted $\mathrm{R}^{2}$ & 0.07 & & 0.28 & & 0.35 & & 0.07 & & 0.29 & & 0.36 & \\
\hline Observations & $1,538,654$ & & $1,538,654$ & & $1,538,654$ & & $1,226,043$ & & $1,226,043$ & & $1,226,043$ & \\
\hline
\end{tabular}


Table 6: Regressions of Idiosyncratic Risk on Firm Characteristics (continued)

Panel C: Time-Series Regressions with Average Firm Characteristics

\begin{tabular}{|c|c|c|c|c|c|c|c|c|c|c|c|c|}
\hline & \multicolumn{6}{|c|}{ 1963-2017 } & \multicolumn{6}{|c|}{ 1983-2017 } \\
\hline & \multicolumn{2}{|c|}{$(1)$} & \multicolumn{2}{|c|}{ (2) } & \multicolumn{2}{|c|}{ (3) } & \multicolumn{2}{|c|}{$(1)$} & \multicolumn{2}{|c|}{$(2)$} & \multicolumn{2}{|c|}{ (3) } \\
\hline & Coef & $p$-value & Coef & $p$-value & Coef & $p$-value & Coef & $p$-value & Coef & $p$-value & Coef & $p$-value \\
\hline Market Risk (Market Model) (log) (lagged) & 0.069 & {$[0.00]$} & & & 0.122 & {$[0.00]$} & -0.029 & {$[0.38]$} & & & 0.093 & {$[0.00]$} \\
\hline Credit Spread (lagged) & 0.048 & {$[0.00]$} & & & 0.069 & {$[0.00]$} & -0.026 & {$[0.29]$} & & & 0.056 & {$[0.00]$} \\
\hline NBER Recessions (lagged) & 0.150 & {$[0.00]$} & & & 0.079 & {$[0.00]$} & 0.295 & {$[0.00]$} & & & 0.069 & {$[0.03]$} \\
\hline Chicago Fed Index (lagged) & -0.012 & {$[0.35]$} & & & -0.007 & {$[0.38]$} & -0.042 & {$[0.04]$} & & & -0.019 & {$[0.11]$} \\
\hline CRSP VW-Return (lagged) & -0.667 & {$[0.00]$} & & & -0.527 & {$[0.00]$} & -1.179 & {$[0.00]$} & & & -0.648 & {$[0.00]$} \\
\hline Illiquidity Ratio (log) (lagged) & & & -0.088 & {$[0.00]$} & 0.019 & {$[0.24]$} & & & 0.018 & {$[0.65]$} & 0.062 & {$[0.09]$} \\
\hline Real Market Capitalization (log) (lagged) & & & -0.318 & {$[0.00]$} & -0.181 & {$[0.00]$} & & & 0.185 & {$[0.02]$} & 0.157 & {$[0.04]$} \\
\hline Firm Age (log) (lagged) & & & -0.415 & {$[0.00]$} & -0.438 & {$[0.00]$} & & & -1.219 & {$[0.00]$} & -1.050 & {$[0.00]$} \\
\hline Book/Market (lagged) & & & 0.297 & {$[0.00]$} & -0.313 & {$[0.00]$} & & & 1.047 & {$[0.00]$} & 0.258 & {$[0.32]$} \\
\hline Leverage (lagged) & & & -0.642 & {$[0.00]$} & -0.011 & {$[0.94]$} & & & 1.242 & {$[0.16]$} & 0.698 & {$[0.40]$} \\
\hline Capital Expenditures/Total Assets (lagged) & & & 2.812 & {$[0.00]$} & 1.801 & {$[0.00]$} & & & 1.030 & {$[0.10]$} & 0.249 & {$[0.68]$} \\
\hline R\&D/Total Assets (lagged) & & & 4.352 & {$[0.00]$} & 5.445 & {$[0.00]$} & & & 3.649 & {$[0.01]$} & 2.845 & {$[0.03]$} \\
\hline Cash and Short-term Investments/Total Assets (log) (lagged) & & & -2.961 & {$[0.00]$} & -2.092 & {$[0.00]$} & & & 0.160 & {$[0.86]$} & -1.173 & {$[0.21]$} \\
\hline ROE (lagged) & & & -2.784 & {$[0.00]$} & -1.069 & {$[0.00]$} & & & -1.280 & {$[0.00]$} & -0.989 & {$[0.02]$} \\
\hline Intercept & -1.202 & {$[0.00]$} & 1.742 & {$[0.00]$} & 1.530 & {$[0.00]$} & -1.236 & {$[0.00]$} & -0.352 & {$[0.52]$} & 0.553 & [0.32] \\
\hline Adjusted $\mathrm{R}^{2}$ & 0.20 & & 0.64 & & 0.74 & & 0.17 & & 0.72 & & 0.77 & \\
\hline Observations & 654 & & 65 & & 65 & & 414 & & 414 & & 414 & \\
\hline
\end{tabular}




\section{Table 7: Forecast Errors in 2013-2017 from Regressions with Firm Characteristics}

The table presents results on forecast errors from firm-level panel regressions (Panel A) and aggregate time-series regressions (Panel B). Results are shown separately for equal-weighting and value-weighting, as well as for the full sample period (1963-2017) and the 1983-2017 subperiod. Idiosyncratic risk is from the market model. To obtain predicted idiosyncratic risk, we run regressions with idiosyncratic risk as dependent variable over the period 1963-2012 and 1983-2012, respectively. The lagged independent variables for the four different models are:

(1) market-model market risk, the credit spread, NBER recessions, the Chicago Fed National Activity Index, the return on the CRSP value-weighted index;

(2) market-model market risk, the credit spread, NBER recessions, the Chicago Fed National Activity Index, the return on the CRSP value-weighted index, book/market, real market capitalization (log), firm age (log);

(3) book/market, illiquidity ratio (log), real market capitalization (log), firm age (log), leverage, capital expenditures/total assets, R\&D expenses/total assets, cash and short-term investments/total assets (log), ROE;

(4) market-model market risk, the credit spread, NBER recessions, the Chicago Fed National Activity Index, the return on the CRSP value-weighted index, book/market, illiquidity ratio (log), real market capitalization (log), firm age (log), leverage, capital expenditures/total assets, R\&D expenses/total assets, cash and short-term investments/total assets (log), ROE.

In Panel A, regressions are based on an unbalanced panel of firm-level observations. We obtain predictions of idiosyncratic risk for each firm in each month over the period 2013-2017 by applying the regression coefficients (alternatively from estimations over the 1963-2012 and 1983-2012 periods) to the observed (lagged) macroeconomic variables and firm characteristics in 2013-2017. We also have actual idiosyncratic risk for each firm in each month from the market model. The difference between actual idiosyncratic risk and predicted idiosyncratic risk is the prediction error for each firm and month in the $2013-2017$ period. We average actual risk, predicted risk, and forecast errors across firms in each month using alternatively equal-weighting or value-weighting (using prior month's market capitalization). The panel reports the time-series mean, median and standard deviation as well as $p$-values of associated tests over the $2013-2017$ period.

Panel B uses aggregate time-series regressions with macroeconomic variables and average firm characteristics to predict average idiosyncratic risk. Idiosyncratic risk (the dependent variable) and firm characteristics are averaged using alternatively equal-weighting or value-weighting (using prior month's market capitalization). Regressions are estimated alternatively over the 1963-2012 and 1983-2012 periods. We obtain predictions of average idiosyncratic risk in each month over the period 2013-2017 by applying the regression coefficients to the observed (lagged) macroeconomic variables and average firm characteristics in 2013-2017. We also have average actual idiosyncratic risk in each month from the market model. The difference between average actual idiosyncratic risk and average predicted idiosyncratic risk is the prediction error for each month in the 2013-2017 period. The panel reports the time-series mean, median and standard deviation as well as $p$-values of associated tests over the 2013-2017 period. $p$-values reported as [0.00] are significant at better than the $1 \%$ level. The sample period is $1 / 1963-6 / 2017$. Appendix A provides definitions of all variables. 
Table 7: Forecast Errors in 2013-2017 from Regressions with Firm Characteristics (continued)

\section{Panel A: Firm-Level Panel Regressions}

\begin{tabular}{|c|c|c|c|c|c|c|c|c|c|c|c|}
\hline & \multirow{2}{*}{$\begin{array}{c}\text { Estimation } \\
\text { Period }\end{array}$} & \multirow[b]{2}{*}{ Model } & \multicolumn{2}{|c|}{$\begin{array}{c}\text { Actual Idiosyncratic } \\
\text { Risk }\end{array}$} & \multicolumn{2}{|c|}{$\begin{array}{c}\text { Predicted } \\
\text { Idiosyncratic Risk }\end{array}$} & \multicolumn{5}{|c|}{ Forecast Error } \\
\hline & & & Mean & Median & Mean & Median & Mean & $p$-value & Median & $p$-value & Std.Dev. \\
\hline \multirow[t]{8}{*}{ Equal-weighting } & $1963-2012$ & (1) & 0.261 & 0.249 & 0.320 & 0.317 & -0.059 & {$[0.00]$} & -0.064 & {$[0.00]$} & 0.034 \\
\hline & & (2) & 0.261 & 0.249 & 0.275 & 0.270 & -0.014 & {$[0.00]$} & -0.018 & {$[0.00]$} & 0.032 \\
\hline & & (3) & 0.261 & 0.249 & 0.283 & 0.283 & -0.023 & {$[0.00]$} & -0.030 & {$[0.00]$} & 0.036 \\
\hline & & (4) & 0.261 & 0.249 & 0.281 & 0.277 & -0.020 & {$[0.00]$} & -0.025 & {$[0.00]$} & 0.032 \\
\hline & 1983-2012 & (1) & 0.261 & 0.249 & 0.318 & 0.316 & -0.057 & {$[0.00]$} & -0.064 & {$[0.00]$} & 0.036 \\
\hline & & (2) & 0.261 & 0.249 & 0.275 & 0.271 & -0.014 & {$[0.00]$} & -0.020 & {$[0.00]$} & 0.033 \\
\hline & & (3) & 0.261 & 0.249 & 0.283 & 0.282 & -0.022 & {$[0.00]$} & -0.030 & {$[0.00]$} & 0.036 \\
\hline & & (4) & 0.261 & 0.249 & 0.276 & 0.273 & -0.016 & {$[0.00]$} & -0.021 & {$[0.00]$} & 0.032 \\
\hline \multirow[t]{8}{*}{ Value-weighting } & 1963-2012 & (1) & 0.168 & 0.166 & 0.314 & 0.313 & -0.145 & {$[0.00]$} & -0.149 & {$[0.00]$} & 0.024 \\
\hline & & (2) & 0.168 & 0.166 & 0.172 & 0.171 & -0.003 & {$[0.31]$} & -0.008 & {$[0.08]$} & 0.023 \\
\hline & & (3) & 0.168 & 0.166 & 0.182 & 0.182 & -0.014 & {$[0.00]$} & -0.014 & {$[0.00]$} & 0.027 \\
\hline & & (4) & 0.168 & 0.166 & 0.175 & 0.175 & -0.007 & {$[0.03]$} & -0.011 & {$[0.00]$} & 0.023 \\
\hline & 1983-2012 & (1) & 0.168 & 0.166 & 0.312 & 0.308 & -0.143 & {$[0.00]$} & -0.147 & {$[0.00]$} & 0.025 \\
\hline & & (2) & 0.168 & 0.166 & 0.171 & 0.170 & -0.002 & {$[0.47]$} & -0.007 & {$[0.13]$} & 0.024 \\
\hline & & (3) & 0.168 & 0.166 & 0.186 & 0.187 & -0.018 & {$[0.00]$} & -0.019 & {$[0.00]$} & 0.027 \\
\hline & & (4) & 0.168 & 0.166 & 0.177 & 0.176 & -0.009 & {$[0.01]$} & -0.013 & {$[0.00]$} & 0.023 \\
\hline
\end{tabular}


Table 7: Forecast Errors in 2013-2017 from Regressions with Firm Characteristics (continued)

\section{Panel B: Aggregate Time-Series Regressions}

\begin{tabular}{|c|c|c|c|c|c|c|c|c|c|c|c|}
\hline & \multirow{3}{*}{$\begin{array}{c}\text { Estimation } \\
\text { Period }\end{array}$} & \multirow[b]{3}{*}{ Model } & \multirow{2}{*}{\multicolumn{2}{|c|}{$\begin{array}{c}\text { Actual Idiosyncratic } \\
\text { Risk }\end{array}$}} & \multicolumn{2}{|c|}{ Predicted } & \multirow{2}{*}{\multicolumn{5}{|c|}{ Forecast Error }} \\
\hline & & & & & Idiosy & atic Risk & & & & & \\
\hline & & & Mean & Median & Mean & Median & Mean & $p$-value & Median & $p$-value & Std.Dev. \\
\hline \multirow[t]{8}{*}{ Equal-weighting } & 1963-2012 & (1) & 0.261 & 0.249 & 0.309 & 0.306 & -0.048 & {$[0.00]$} & -0.052 & {$[0.00]$} & 0.033 \\
\hline & & (2) & 0.261 & 0.249 & 0.216 & 0.213 & 0.045 & {$[0.00]$} & 0.041 & {$[0.00]$} & 0.031 \\
\hline & & (3) & 0.261 & 0.249 & 0.239 & 0.240 & 0.022 & {$[0.00]$} & 0.013 & {$[0.00]$} & 0.035 \\
\hline & & (4) & 0.261 & 0.249 & 0.221 & 0.217 & 0.039 & {$[0.00]$} & 0.037 & {$[0.00]$} & 0.030 \\
\hline & 1983-2012 & (1) & 0.261 & 0.249 & 0.305 & 0.303 & -0.044 & {$[0.00]$} & -0.050 & {$[0.00]$} & 0.036 \\
\hline & & (2) & 0.261 & 0.249 & 0.213 & 0.206 & 0.048 & {$[0.00]$} & 0.043 & {$[0.00]$} & 0.030 \\
\hline & & (3) & 0.261 & 0.249 & 0.257 & 0.256 & 0.004 & {$[0.35]$} & -0.001 & {$[0.69]$} & 0.031 \\
\hline & & (4) & 0.261 & 0.249 & 0.243 & 0.241 & 0.018 & {$[0.00]$} & 0.015 & {$[0.01]$} & 0.029 \\
\hline \multirow[t]{8}{*}{ Value-weighting } & 1963-2012 & (1) & 0.168 & 0.166 & 0.200 & 0.200 & -0.032 & {$[0.00]$} & -0.036 & {$[0.00]$} & 0.024 \\
\hline & & (2) & 0.168 & 0.166 & 0.165 & 0.163 & 0.004 & {$[0.23]$} & 0.000 & {$[0.72]$} & 0.023 \\
\hline & & (3) & 0.168 & 0.166 & 0.175 & 0.174 & -0.006 & {$[0.05]$} & -0.010 & {$[0.01]$} & 0.023 \\
\hline & & (4) & 0.168 & 0.166 & 0.158 & 0.151 & 0.011 & {$[0.00]$} & 0.007 & {$[0.02]$} & 0.022 \\
\hline & 1983-2012 & (1) & 0.168 & 0.166 & 0.198 & 0.199 & -0.030 & {$[0.00]$} & -0.034 & {$[0.00]$} & 0.024 \\
\hline & & (2) & 0.168 & 0.166 & 0.147 & 0.144 & 0.021 & {$[0.00]$} & 0.019 & {$[0.00]$} & 0.022 \\
\hline & & (3) & 0.168 & 0.166 & 0.173 & 0.171 & -0.004 & {$[0.17]$} & -0.010 & [0.03] & 0.022 \\
\hline & & (4) & 0.168 & 0.166 & 0.154 & 0.153 & 0.015 & {$[0.00]$} & 0.008 & {$[0.00]$} & 0.022 \\
\hline
\end{tabular}




\section{Table 8: Regressions of Market Risk and R-Squared on 5-year Period Dummies}

The table shows results from regressions of average monthly annualized market risk (Panel A) and regression Rsquared (Panel B) on an intercept and indicator variables for non-overlapping 5-year periods. Market risk is alternatively from the market model and the CLMX model. R-Squared is alternatively from the market model and the FamaFrench 5-factor model. Values are averaged each month either using equal-weighting or value-weighting (using prior month's market capitalization). The table shows the regression coefficients and associated $p$-values, as well as the regression R-squared and the number of time-series observations. $p$-values reported as $[0.00]$ are significant at better than the $1 \%$ level. The sample period is 1/1963-6/2017. Appendix A provides definitions of all variables.

Panel A: Market Risk

\begin{tabular}{|c|c|c|c|c|c|c|c|c|}
\hline & \multicolumn{4}{|c|}{ Equally-weighted Market Risk } & \multicolumn{4}{|c|}{ Value-weighted Market Risk } \\
\hline & \multicolumn{2}{|c|}{ Market Model } & \multicolumn{2}{|c|}{ CLMX Model } & \multicolumn{2}{|c|}{ Market Model } & \multicolumn{2}{|c|}{ CLMX Model } \\
\hline & Coef & $p$-value & Coef & $p$-value & Coef & $p$-value & Coef & $p$-value \\
\hline Intercept & 0.142 & {$[0.00]$} & 0.119 & {$[0.00]$} & 0.118 & {$[0.00]$} & 0.119 & {$[0.00]$} \\
\hline Years 2008-2012 & 0.115 & {$[0.00]$} & 0.087 & {$[0.00]$} & 0.095 & {$[0.00]$} & 0.087 & {$[0.00]$} \\
\hline Years 2003-2007 & 0.004 & {$[0.73]$} & 0.006 & {$[0.55]$} & 0.008 & {$[0.52]$} & 0.006 & {$[0.55]$} \\
\hline Years 1998-2002 & 0.039 & {$[0.00]$} & 0.092 & {$[0.00]$} & 0.093 & {$[0.00]$} & 0.092 & {$[0.00]$} \\
\hline Years 1993-1997 & -0.038 & {$[0.00]$} & -0.017 & {$[0.12]$} & -0.011 & {$[0.33]$} & -0.017 & [0.12] \\
\hline Years 1988-1992 & -0.031 & {$[0.01]$} & 0.001 & [0.89] & 0.004 & {$[0.73]$} & 0.001 & [0.89] \\
\hline Years 1983-1987 & -0.031 & {$[0.01]$} & 0.005 & {$[0.61]$} & 0.012 & {$[0.29]$} & 0.005 & [0.61] \\
\hline Years 1978-1982 & -0.022 & {$[0.05]$} & 0.014 & {$[0.21]$} & 0.014 & {$[0.24]$} & 0.014 & {$[0.21]$} \\
\hline Years 1973-1977 & -0.020 & {$[0.08]$} & 0.018 & {$[0.09]$} & 0.020 & {$[0.09]$} & 0.018 & {$[0.09]$} \\
\hline Years 1968-1972 & -0.024 & {$[0.03]$} & -0.017 & {$[0.12]$} & -0.015 & {$[0.20]$} & -0.017 & [0.12] \\
\hline Years 1963-1967 & -0.064 & {$[0.00]$} & -0.045 & {$[0.00]$} & -0.042 & {$[0.00]$} & -0.045 & {$[0.00]$} \\
\hline $\mathrm{R}^{2}$ & 0.38 & & 0.33 & & 0.30 & & 0.33 & \\
\hline Observations & 654 & & 654 & & 654 & & 654 & \\
\hline
\end{tabular}

Panel B: R-Squared

\begin{tabular}{|c|c|c|c|c|c|c|c|c|}
\hline & \multicolumn{4}{|c|}{ Equally-weighted R-Squared } & \multicolumn{4}{|c|}{ Value-Weighted R-Squared } \\
\hline & \multicolumn{2}{|c|}{ Market Model } & \multicolumn{2}{|c|}{$\begin{array}{c}\text { Fama-French 5- } \\
\text { Factor Model }\end{array}$} & \multicolumn{2}{|c|}{ Market Model } & \multicolumn{2}{|c|}{$\begin{array}{c}\text { Fama-French 5- } \\
\text { Factor Model }\end{array}$} \\
\hline & Coef & $p$-value & Coef & $p$-value & Coef & $p$-value & Coef & $p$-value \\
\hline Intercept & 0.290 & [0.00] & 0.501 & [0.00] & 0.364 & [0.00] & 0.560 & {$[0.00]$} \\
\hline Years 2008-2012 & 0.088 & {$[0.00]$} & 0.052 & {$[0.00]$} & 0.088 & {$[0.00]$} & 0.058 & {$[0.00]$} \\
\hline Years 2003-2007 & -0.051 & [0.00] & -0.067 & [0.00] & -0.027 & [0.12] & -0.037 & [0.01] \\
\hline Years 1998-2002 & -0.141 & {$[0.00]$} & -0.139 & {$[0.00]$} & -0.077 & {$[0.00]$} & -0.063 & {$[0.00]$} \\
\hline Years 1993-1997 & -0.188 & {$[0.00]$} & -0.192 & {$[0.00]$} & -0.160 & {$[0.00]$} & -0.144 & {$[0.00]$} \\
\hline Years 1988-1992 & -0.168 & {$[0.00]$} & -0.180 & {$[0.00]$} & -0.074 & {$[0.00]$} & -0.092 & {$[0.00]$} \\
\hline Years 1983-1987 & -0.156 & {$[0.00]$} & -0.162 & {$[0.00]$} & -0.092 & {$[0.00]$} & -0.094 & {$[0.00]$} \\
\hline Years 1978-1982 & -0.133 & {$[0.00]$} & -0.137 & {$[0.00]$} & -0.079 & {$[0.00]$} & -0.079 & {$[0.00]$} \\
\hline Years 1973-1977 & -0.150 & {$[0.00]$} & -0.163 & {$[0.00]$} & -0.059 & {$[0.00]$} & -0.082 & {$[0.00]$} \\
\hline Years 1968-1972 & -0.145 & {$[0.00]$} & -0.153 & [0.00] & -0.139 & {$[0.00]$} & -0.128 & {$[0.00]$} \\
\hline Years 1963-1967 & -0.170 & {$[0.00]$} & -0.182 & [0.00] & -0.157 & {$[0.00]$} & -0.149 & {$[0.00]$} \\
\hline $\mathrm{R}^{2}$ & 0.62 & & 0.65 & & 0.36 & & 0.40 & \\
\hline Observations & 654 & & 648 & & 654 & & 648 & \\
\hline
\end{tabular}




\section{Appendix A: Variable Definitions}

The table shows the names and definitions of the main variables used in the paper.

\begin{tabular}{|c|c|}
\hline Variable & Definition \\
\hline \multicolumn{2}{|l|}{ Panel A: Macroeconomic variables } \\
\hline Chicago Fed Index & $\begin{array}{l}\text { Chicago Fed National Activity Index: Total (CFNAITot). We use a regression } \\
\text { analysis to construct values of CFNAITot prior to March } 1967 \text { using available } \\
\text { subcomponents. }\end{array}$ \\
\hline CreditSpread & $\begin{array}{l}\text { Difference between Moody's seasoned Baa corporate bond yield provided by } \\
\text { Board of Governors of the Federal Reserve System, averages of business } \\
\text { days (H.15 release) (BAA) and Constant maturity 10-year U.S. Treasury yield } \\
\text { provided by Board of Governors of the Federal Reserve System, averages of } \\
\text { business days (H.15 release) (GS10) }\end{array}$ \\
\hline CRSP Index Volatility & $\begin{array}{l}\text { Annualized monthly volatility of CRSP value-weighted market return } \\
\text { calculated using daily return observations. }\end{array}$ \\
\hline CRSP VW-Return & Return on CRSP value-weighted stock market index (incl. dividends) \\
\hline Economic Policy Uncertainty Index & $\begin{array}{l}\text { Measure policy-related economic uncertainty (from } \\
\text { www.PolicyUncertainty.com) }\end{array}$ \\
\hline NBER Recessions & $\begin{array}{l}\text { Indicator variable with value equal to } 1 \text { for months during an NBER-dated } \\
\text { recession; } 0 \text { otherwise. }\end{array}$ \\
\hline Uncertainty Index & $\begin{array}{l}\text { Uncertainty index based on the detrended cross-sectional standard deviation } \\
\text { of GDP growth forecasts (from Kozeniauskas, Orlik and Velkamp (2014)) }\end{array}$ \\
\hline VIX Index & Implied Volatility Index (CBOE) \\
\hline \multicolumn{2}{|l|}{ Panel B: Firm-level variables } \\
\hline Book/Market & $($ Common Equity + Deferred Taxes $($ Balance Sheet))/Market Capitalization \\
\hline Capital Expenditures/Total Assets & Capital Expenditures/Total Assets \\
\hline Cash and Short-term Investments/Total Assets & Cash and Short-term Investments / Total Assets \\
\hline Firm Age & $\begin{array}{l}\text { Difference in years between the observation date and the date of the first } \\
\text { price on CRSP. }\end{array}$ \\
\hline Idiosyncratic Risk (CLMX Model 5-Day Returns) & $\begin{array}{l}\text { Idiosyncratic risk from CLMX model using daily returns of rolling 5-day } \\
\text { returns in a month }\end{array}$ \\
\hline Idiosyncratic Risk (CLMX Model) & Idiosyncratic risk from CLMX model using daily returns in a month \\
\hline Idiosyncratic Risk (Fama-French 5-Factor Model) & Idiosyncratic risk from Fama French 5-factor model \\
\hline Idiosyncratic Risk (Market Model) & Idiosyncratic risk from market model \\
\hline Illiquidity Ratio & Monthly average of (Absolute Stock Return/Stock Trading Volume) \\
\hline Institutional Ownership & Fraction of shares outstanding owned by institutional investors. \\
\hline Leverage & $\begin{array}{l}\text { (Total Debt }+ \text { Preferred Stock }) /(\text { Total Debt }+ \text { Preferred Stock }+ \text { Market } \\
\text { Capitalization })\end{array}$ \\
\hline Market Risk (CLMX Model 5-Day Returns) & $\begin{array}{l}\text { Market risk from market model using daily returns of rolling 5-day returns in a } \\
\text { month }\end{array}$ \\
\hline Market Risk (CLMX Model) & Market risk from CLMX model \\
\hline Market Risk (Market Model) & Market risk from market model using daily returns in a month \\
\hline R\&D Expenses/Total Assets & R\&D Expenses/Total Assets \\
\hline Real Market Capitalization & Market capitalization in millions of 1997 dollars \\
\hline Revenue Herfindahl Index & $\begin{array}{l}\text { Revenue Herfindahl Index based on 3-digit historical NAICS (Kahle and } \\
\text { Stulz, 2017) }\end{array}$ \\
\hline ROE & Return on Equity (Net Income/Shareholders' Equity) \\
\hline S\&P Constituent & $\begin{array}{l}\text { Indicator variable with value } 1 \text { if stock is member of the S\&P } 500 \text { index; } 0 \\
\text { otherwise. }\end{array}$ \\
\hline Total Debt & Current Liabilities + Long-Term Debt \\
\hline Total Risk & Standard deviation of daily returns in a month \\
\hline
\end{tabular}

